
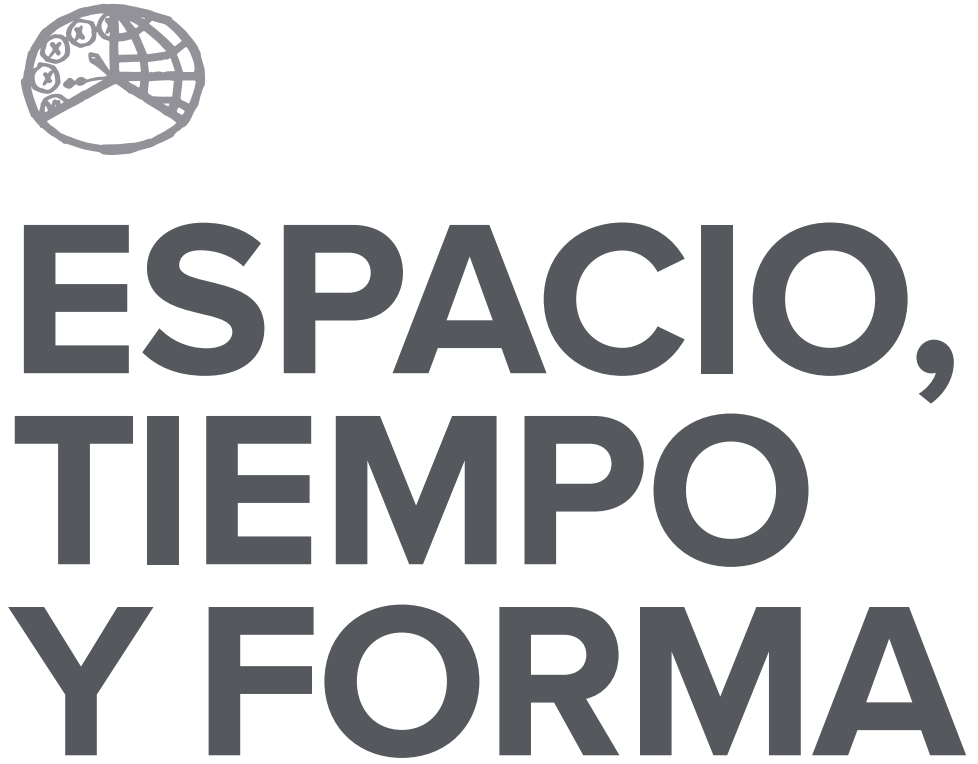

AÑO 2021

ISSN 0214-9745

E-ISSN 2340-1362

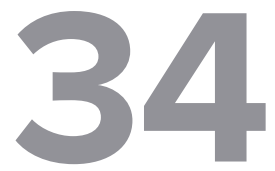

SERIE III HISTORIA MEDIEVAL

REVISTA DE LA FACULTAD DE GEOGRAFÍA E HISTORIA

VOLUMEN I 


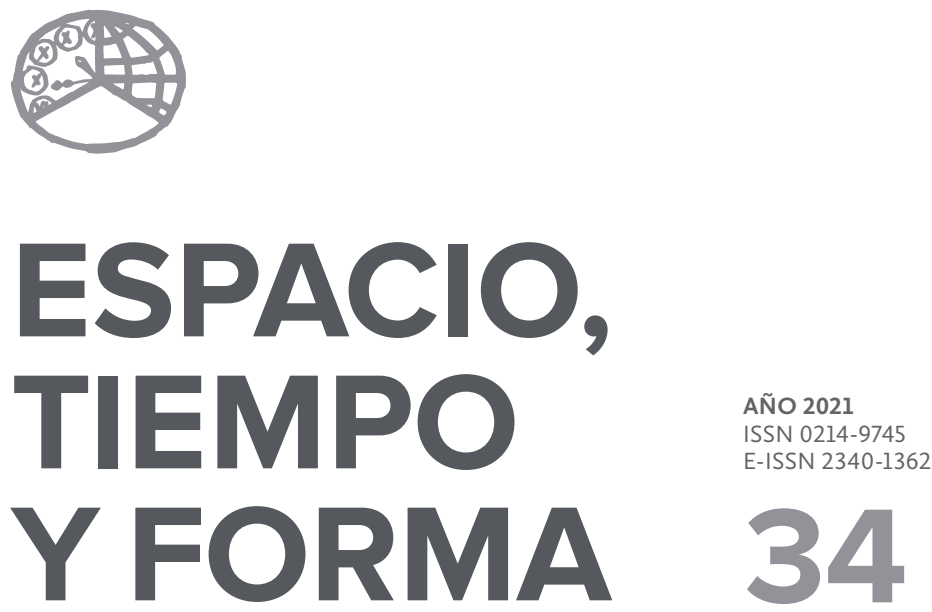

SERIE III HISTORIA MEDIEVAL

REVISTA DE LA FACULTAD DE GEOGRAFÍA E HISTORIA

VOLUMEN I

http://dx.doi.org/10.5944/etfiii.34.2021

\section{UกED}

UNIVERSIDAD NACIONAL DE EDUCACIÓN A DISTANCIA 
La revista Espacio, Tiempo y Forma (siglas recomendadas: ETF),

de la Facultad de Geografía e Historia de la UNED, que inició su publicación el año 1988, está organizada de la siguiente forma:

$$
\begin{aligned}
& \text { SERIE I - Prehistoria y Arqueología } \\
& \text { SERIE II - Historia Antigua } \\
& \text { SERIE III - Historia Medieval } \\
& \text { SERIE IV - Historia Moderna } \\
& \text { SERIE V - Historia Contemporánea } \\
& \text { SERIE VI - Geografía } \\
& \text { SERIE VII - Historia del Arte }
\end{aligned}
$$

Excepcionalmente, algunos volúmenes del año 1988 atienden a la siguiente numeración:
N. ${ }^{\circ} 1 \quad-$ Historia Contemporánea
N. ${ }^{\circ} 2-$ Historia del Arte
N. ${ }^{\circ} 3-$ Geografía
N. ${ }^{\circ} 4 \quad-$ Historia Moderna

ETF no se solidariza necesariamente con las opiniones expresadas por los autores.

UNIVERSIDAD NACIONAL DE EDUCACIÓN A DISTANCIA

Madrid, 2021

SERIE III - HISTORIA MEDIEVAL N. ${ }^{\circ} 34,2021$

ISSN 0214-9745 · E-ISSN 2340-1362

DEPÓSITO LEGAL M-21037-1988

URL: ETF III · HISTORIA MEDIEVAL · http://revistas.uned.es/index.php/ETFIII

DISEÑO Y COMPOSICIÓN

Carmen Chincoa Gallardo · http://www.laurisilva.net/cch

Impreso en España $\cdot$ Printed in Spain 
Espacio, Tiempo y Forma. Serie III. Historia Medieval es la revista científica fundada en I988 que publica el Departamento de Historia Medieval y Ciencias y Técnicas Historiográficas de la Facultad de Geografía e Historia de la UNED. Está dedicada al estudio de la Historia Medieval y acoge trabajos inéditos de investigación, en especial artículos que constituyan una aportación novedosa, que enriquezcan el campo de estudio que abordan y que ofrezcan una perspectiva de análisis crítico. Va dirigida preferentemente a la comunidad científica y universitaria, tanto nacional como internacional, así como a todos los profesionales de la Historia Medieval en general. Su periodicidad es anual y se somete al sistema de revisión por pares ciegos. La revista facilita el acceso sin restricciones a todo su contenido desde el momento de su publicación en edición electrónica. Espacio, Tiempo y Forma. Serie III. Historia Medieval se publica en formato electrónico y en papel.
Espacio, Tiempo y Forma. Serie III. Historia Medieval (Space, Time and Form. Series III. Medieval History) is a peerreviewed academic journal founded in I988 and published by the Department of Medieval History and Historiographical Sciences and Techniques at the Faculty of Geography and History, UNED. It is devoted to the study of Medieval History and is addressed to the Spanish and international scholarly community, as well as to professionals in the field of Medieval History. The journal welcomes previously unpublished articles, particularly works that provide an innovative approach, contribute to its field of research and offer a critical analysis. It is published annually. The journal provides complete open access to its content available online upon publication. Espacio, Tiempo y Forma. Serie III. Historia Medieval is published online and in print and is indexed in the databases and directories enumerated below.

Espacio, Tiempo y Forma. Serie III. Historia Medieval está registrada e indexada en Repertorios Bibliográficos y Bases de Datos nacionales e internacionales, como recomiendan los criterios de la Comisión Nacional Evaluadora de la Actividad Investigadora: LATINDEX, DICE, ISOC (CINDOC), RESH, INRECH, Dialnet, e-spacio UNED, CIRC 2.o (20I6), MIAR, FRANCIS, PIO, Ulrich's, SUDOC, ZDB, ERIH (ESF), REDIB, Repertorio de Medievalismo Hispánico, Directory of Open Access Journals (DOAJ), Emerging Sources Citation Index (ESCI), SCOPUS. La revista ha obtenido el Sello de Calidad de la FECYT (2018).

\section{EQUIPO EDITORIAL}

Edita: Departamento de Historia Medieval y Ciencias y Técnicas Historiográficas, Universidad Nacional de Educación a Distancia

Director del Consejo de Redacción: Enrique Cantera Montenegro (UNED)

Editores: Enrique Cantera Montenegro (UNED), Carlos Barquero Goñi (UNED) 
CONSEJO DE REDACCIÓN

Cristina Álvarez Millán

Departamento de Historia Medieval y Ciencias y Técnicas Historiográficas, UNED

Ana Arranz Guzmán

Universidad Complutense de Madrid

Carlos de Ayala Martínez

Universidad Autónoma de Madrid

Carlos Barquero Goñi

Departamento de Historia Medieval y Ciencias y Técnicas Historiográficas, UNED

Enrique Cantera Montenegro

Departamento de Historia Medieval y Ciencias y Técnicas Historiográficas, UNED

Ana Echevarría Arsuaga

Departamento de Historia Medieval y Ciencias y Técnicas Historiográficas, UNED

José María de Francisco Olmos

Universidad Complutense de Madrid

María Jesús Fuente Pérez

Universidad Carlos III de Madrid

Manuel Fernando Ladero Quesada

Departamento de Historia Medieval y Ciencias y Técnicas Historiográficas, UNED

Paulina López Pita

Departamento de Historia Medieval y Ciencias y Técnicas Historiográficas, UNED

José Miguel López Villalba

Departamento de Historia Medieval y Ciencias y Técnicas Historiográficas, UNED

José María Monsalvo Antón

Universidad de Salamanca

Isabel Montes Romero-Camacho

Universidad de Sevilla

Gonzalo Viñuales Ferreiro

Universidad Rey Juan Carlos

COMITÉ CIENTÍFICO

Vicente Ángel Álvarez Palenzuela

Universidad Autónoma de Madrid

Daniel Baloup

Université de Toulouse-Le Mirail

Vicente García Lobo

Universidad de León

María Estela González de Fauve

Universidad de Buenos Aires · Fundación para la Historia de España

César González Mínguez

Universidad del País Vasco 
Nikolas Jaspert

Ruhr-Universität Bochum, Alemania

DIRECTORA DE ETF SERIES I-VII

Yayo Aznar Almazán

Decana Facultad de Geografía e Historia, UNED

SECRETARIO DE ETF SERIES I-VII

Julio Fernández Portela

Departamento de Geografía, UNED

GESTORA PLATAFORMA OJS

Carmen Chincoa Gallardo

COMITÉ EDITORIAL DE ETF SERIES I-VII

Carlos Barquero Goñi, Departamento de Historia Medieval y Ciencias y Técnicas Historiográficas, UNED; Enrique Cantera Montenegro, Departamento de Historia Medieval y Ciencias y Técnicas Historiográficas, Uned; Pilar Díez del Corral Corredoira, Departamento de Historia del Arte, UneD; Carmen Guiral Pelegrín, Departamento de Prehistoria y Arqueología (Arqueología), Uned; Patricia Hevia Gómez, Departamento de Prehistoria y Arqueología (Arqueología), unED; Luiza lordache Cârstea, Departamento de Historia Contemporánea, UNED; M. ${ }^{a}$ Luisa de Lázaro Torres, Departamento de Geografía, Uned; David Martín Marcos, Departamento de Historia Moderna, Uned; José Antonio Martínez Torres, Departamento de Historia Moderna, UnED; Íñigo García Martínez de Lagrán, Departamento de Prehistoria y Arqueología (Prehistoria), UnED; Álvaro Molina Martín, Departamento de Historia del Arte, Uned; Francisco Javier Muñoz Ibáñez, Departamento de Prehistoria y Arqueología (Prehistoria), UNED; Rocío Negrete Peña, Departamento de Historia Contemporánea, UnED; Miguel Ángel Novillo López, Departamento de Historia Antigua, UnED.

CORRESPONDENCIA

Revista Espacio, Tiempo y Forma

Facultad de Geografía e Historia, UNED

c/ Senda del Rey, 7

28040 Madrid

e-mail: revista-etf@geo.uned.es 



\section{SUMARIO · SUMMARY}

\section{VOLUMEN I}

13 Artículos $\cdot$ Articles

15 Patricia A. Argüelles Álvarez

Peligros, inseguridades y problemas del viajero visigodo

Danger, Lack of Safety and Problems for the Visigothic Traveller

37 Carmen Barceló, Ana labarta, Josep Benedito \& José M. Melchor Cuatro cerámicas con epigrafía árabe del Museu de Borriana

Four Ceramic Pieces with Arabic Inscriptions in the Archeological Museum of Borriana

65 Carlos Barquero Goñ

Organización de la Orden de San Juan en Castilla durante los siglos XII y XIII The Organization of the Order of Saint John in Castile during the Twelfth and Thirteenth Centuries

113 Francisco de Paula Cañas Gálvez

Una infanta de Navarra en la corte de Castilla: escenarios políticos en torno a la configuración y evolución del Hostal y la casa de Blanca de Trastámara, Princesa de Asturias (I424-†I464)

A Princess of Navarre in the Court of Castile: Political Scenarios in the Configuration and Evolution of the Hostal and Royal Household of Blanca of Trastámara, Princess of Asturias (I424-†I464)

165 David Caramazana Malia

Las promociones artísticas de Alonso de Ejea, arzobispo y administrador perpetuo de la Archidiócesis de Sevilla y patriarca de Constantinopla (I403-I4I7)

The Artistic Patronage of Alonso de Ejea, Archbishop and Perpetual Administrator of the Archdiocese of Seville and Patriarch of Constantinople (I403-I4I7) 
203 Pedro Castillo Maldonado

Privilegios episcopales: la inviolabilidad de los obispos visigóticos y el delito de lesa majestad

Episcopal Privileges: The Inviolability of Visigothic Bishops and the Crime of Lèse-Majesté

227 Máximo Diago HERnANDO

Alonso de Fonseca, Obispo de Ávila, Cuenca y Osma, y el ascenso de un linaje de exiliados portugueses en la Castilla de los siglos XV y XVI Alonso de Fonseca, Bishop of Ávila, Cuenca and Osma, and the Promotion in Castile of an Exiled Noble Family from Portugal during the Fifteenth and Sixteenth Centuries

263 Antonio PIO DI Cosmo

Santa Brigida ed il Monte Gargano: un paesaggio dell'anima. La descrizione dell'ambiente come stratagemma d'ammaestramento morale Saint Brigid and Mount Gargano: A Landscape of the Soul. The Description of the Environment as a Device for Moral Instruction

Santa Brígida y el Monte Gargano: un paisaje del alma. La descripción del medio ambiente como estrategia de entrenamiento moral

293 FERRAN ESQUiLACHE

La 'fila' de agua valenciana y otras medidas de aforo. La verdadera naturaleza de un sistema de medición de caudales de origen andalusí

The Valencian Water 'Fila' and other Systems of Gauging Liquid Capacity. The Actual Nature of a Measurement System of Water Flow of Andalusí Origin

323 Alejandro Esteban Álvarez

Habices del Reino de Granada averiguados en I528 y I53I: la țā‘a nazarí de Órgiva (Alpujarra)

Habices of the Kingdom of Granada Ascertained in 1528 and I53I: The Nasrid tạa'a of Órgiva (Alpujarra)

359 Javier Gómez Gómez e Iñakı Martín Viso

Rationes y decimas: evidencias sobre la gestión de las sernas en el siglo Xl en el noroeste de la Península Ibérica

Rationes and Decimas: Some Evidences on the Management of Eleventh Century Sernas in Northwestern Iberia 
383 Santiago González Sánchez

Aportaciones de Paredes de Nava a las campañas militares del Infante Don Fernando, señor de la villa y regente de Castilla, contra el Reino Nazarí de Granada en I407 y en I4IO

The Contribution of Paredes de Nava to the Military Campaigns of the Infante Fernando, Lord of the Town and Regent of Castile, against the Nasrid Kingdom of Granada in 1407 and I4IO

429 ANTONI LLIBRER ESCRIG

Una máquina para la industria medieval. Los batanes del sur valenciano: integración y negocio. Nuevas aportaciones (I49O-I502)

A Machine for Medieval Industry. The Fulling Mills of the Valencian South: Integration and Business. New contributions (I49O-I502)

455 José Miguel López Villalba

Comunicación escrita y oral de la ordenanza municipal (siglos XV-XVI) Written and Oral Communication of Municipal Regulations (FifteenthSixteenth Centuries)

501 Emilio Martín Gutiérrez

El aprovechamiento de los recursos naturales: la grana en Andalucía occidental durante el siglo XV

The Use of Natural Resources: Grana Pigmentin Western Andalusia during the Fifteenth Century

\section{VOLUMEN II}

537 Vera-Cruz Miranda Menacho

Las finanzas de un heredero: Carlos de Aragón y Navarra (I42I-I46I)

A Crown Prince's Finances: Charles of Aragon and Navarre (I42I-I46I)

569 Raúl Morales Muñoz

Hacia una revalorización del conciliarismo hispano bajomedieval: el Defensorium Trium Conclusionum de Alfonso de Madrigal

Towards a Reappraisal of Late-Medieval Hispanic Conciliarism: Alfonso de Madrigal's Defensorium Trium Conclusionum 
605 David Nogales Rincón

Enrique III de Castilla (I390-I406) y la indagación de rentas: un proyecto regio para la búsqueda de mineros y tesoros a inicios del cuatrocientos Enrique III of Castile (I390-I406) and the Inquiry into Sources of Revenue: A Royal Project for the Quest of Mines And Treasures at the Turn of the Fifteenth Century

647 Gonzalo Oliva Manso

Seisenes y novenes. Tiempos de calma para la moneda castellano-leonesa (I282-I3I2)

The Seisén and the Novén. Times of Stability for the Castile-Leonese Currency (I282-I3I2)

685 Alberto Peña Fernández y Manuel García Alonso Una inscripción medieval inédita en la iglesia de San Miguel de Aguayo (Cantabria)

A Newly Found Medieval Inscription in the Church of San Miguel de Aguayo (Cantabria)

713 Rodrigo Pousa Diéguez

Configuración institucional de una villa costera: Muros en el tránsito de la Edad Media a la Edad Moderna

The Institutional Development of a Coastal Village: Muros between the Middle Ages and the Early Modern Times

745 Juan A. Prieto Sayagués

Las profesiones femeninas de la nobleza y de las oligarquías urbanas en la Castilla bajomedieval. Causas, dinámicas, privilegios y donaciones

Female Professions among the Nobility and the Urban Oligarchy in Late Medieval Castile. Causes, Dynamics, Privileges and Donations

815 María del Pilar Rábade Obradó

El miedo a la Inquisición en la Castilla de los Reyes Católicos

Fear of the Inquisition in Castile under the Catholic Monarchs

845 Carlos Manuel Reglero de la Fuente

EL abad contra el rey (y los regidores): conflicto de jurisdicciones y ejercicio del poder en Sahagún (I398-I4I7)

The Abbot versus The King (and the Town Councillors): Conflict between Jurisdictions and the Use of Power in Sahagún (I398-I4I7) 
881 Manuel Alejandro Rodríguez de la Peña

Eusebius and Alcuin on Constantine and Charlemagne as Wise Rulers:

Sapiential Rulership in Late Antiquity and the Early Middle Ages

Constantino y Carlomagno como gobernantes sabios en la obra de Eusebio de Cesarea y Alcuino de York: la realeza sapiencial en la Antigüedad Tardía y la Alta Edad Media

915 Antonio SÁnchez González

El Archivo de los Mariscales de Castilla y Marqueses de Malagón

The Archives of the Marshals of Castile and the Marquises of Malagón

\section{Estudios y comentarios}

951 Serafín Olcoz Yanguas

Apostilla al estudio Influencia de las redes nobiliarias en la expansión cristiana del siglo XII: el caso de Soria (ETF, 33, 2020)

Notes on the Article The Influence of Aristocratic Networks on the Christian Expansion of the Twelfth Century. The Case of Soria $(E T F, 33,2020)$

\section{Libros $\cdot$ Books}

969 CASTRIllo CASAdo, Janire, Las mujeres vascas durante la Baja Edad Media (María Jesús Fuente)

973 Crónica del rey Juan II de Castilla. Minoría y primeros años de reinado (I406I420). Garcia, Michel (edición y estudio) (Víctor MuÑoz Gómez)

981 Da Silva, Marcelo Cândido, História Medieval (Diego Carlo Améndolla SPÍNOLA)

987 Galende Díaz, Juan Carlos y Ávila SeoAne, Nicolás, El rodado regio hispánico. Fernando III de León y Castilla (I23O-I252) (MAURicio Herrero JIMÉNEZ)

989 GARcía IzQuiERdo, Iván, Frontera, fuero y concejos. El valle del Riaza en la Edad Media (siglos VIII-XII) (CARLOS BARQUERO GOÑI)

993 García IzQuierdo, Iván y Peterson, David (coords.), Camino y Señorío. Obra selecta de Luis Martínez García (Enrique Cantera Montenegro) 
995 González Paz, Carlos Andrés, O Bispado de Mondoñedo na Idade Media. Territorio, comunidade e poder (ENRIQue CANTERA Montenegro)

997 López Martínez, Amalia, Minutarios notariales de Estevo Pérez (Ourense, siglo XIV) (José Miguel López Villalba)

999 Miranda García, Fermín y López de Guereño Sanz, María Teresa (eds.), La muerte de los príncipes en la Edad Media. Balance y perspectivas historiográficas (ANA Echevarría Arsuaga)

1003 Motis Dolader, Miguel Ángel, Vivencias, emociones y perfiles femeninos. Judeoconversas e Inquisición en Aragón en el siglo XV (ANA EcheVARRía ArSUAGA)

1007 Solórzano Telechea, Jesús Ángel y Martín Pérez, Fernando (coords.), Rutas de comunicación marítima y terrestre en los reinos hispánicos durante la Baja Edad Media. Movilidad, conectividad y gobernanza (ENRIQUe José Ruiz Pilares)

1013 Torre, Sandra de la - Etxeberria, Ekaitz - Díaz de Durana, José Ramón (coords.), Valer más en la tierra. Poder, violencia y linaje en el País Vasco bajomedieval (EnRIQue CANTERA Montenegro)

1015 TRIllo SAN José, Carmen, La Vega de Granada a partir de documentación árabe romanceada inédita (I457-I494). Estudio, edición e índices (INMACULADA GONZÁlez SopeÑA)

1019 Val Valdivieso, M. ${ }^{a}$ Isabel - Villanueva Zubizarreta, Olatz (Coords.), Pero Ansúrez. El conde, su época y su memoria (Enrique CANTERA Montenegro)

1021 Villanueva Morte, Concepción y Fernández de Córdova Miralles, Álvaro, El embajador Claver. Diplomacia y conflicto en las «Guerras de Italia» (I495-I504) (ENRIQUe CANTERA MONTENEGRO)

1023 Normas de publicación · Authors Guidelines 


\section{ARTÍCULOS · ARTICLES}

\section{VOLUMEN I}





\title{
APORTACIONES DE PAREDES DE NAVA A LAS CAMPAÑAS MILITARES DEL INFANTE DON FERNANDO, SEÑOR DE LA VILLA Y REGENTE DE CASTILLA, CONTRA EL REINO NAZARÍ DE GRANADA EN 1407 Y EN 1410
}

\section{THE CONTRIBUTION OF PAREDES DE NAVA TO THE MILITARY CAMPAIGNS OF THE INFANTE FERNANDO, LORD OF THE TOWN AND REGENT OF CASTILE, AGAINST THE NASRID KINGDOM OF GRANADA IN 1407 AND 1410}

\author{
Santiago González Sánchez ${ }^{1}$
}

Recepción: 2020/02/02 · Comunicación de observaciones de evaluadores: 2020/09/11 . Aceptación: 2020/09/12

DOI: https://dx.doi.org/10.5944/etfiii.34.2021.30047

\section{Resumen}

Este artículo estudia las aportaciones que la villa de Paredes de Nava (Palencia) hizo a las campañas militares del infante don Fernando, el de Antequera, señor de la villa y regente de Castilla, contra el reino nazarí de Granada en I407 y, sobre todo, en I4Io. Se presta especial atención a esta última, pues es de la que tenemos más documentación. En tal sentido se analizan la elección de los combatientes -principal contribución de la villa en I4IO-, su permanencia en la campaña o su conducta, pasando por el posible momento de su salida y el itinerario seguido. Se abordan los aspectos hacendístico-fiscales que conllevaba la movilización y el desplazamiento de tan importante contingente de combatientes y sus repercusiones en la hacienda de Paredes de Nava: imposición de tributos extraordinarios, posibles préstamos y disminución de ingresos. También se tratan de forma breve las informaciones

1. Doctor en Historia Medieval UCM. IES Santo Domingo. El Puerto de Santa María, Cádiz. C.e.: santitrifo@gmail.com. ORCID: https://orcid.org/0000-0003-1823-3833 
que llegaban a Paredes sobre la evolución de la guerra y los gastos que el concejo hizo en festejos para celebrar la victoria castellana.

\section{Palabras clave}

Paredes de Nava; campaña militar; Setenil; Antequera; infante don Fernando; siglo XV; ballesteros; lanceros.

\section{Abstract}

This article looks at the contribution made by the town of Paredes de Nava to the military campaigns of the Infante Fernando -known as «de Antequera»- lord of the town and regent of Castile, against the Nasrid kingdom of Granada in 1407 and I4Io. Special attention is given to the military campaigns of I4Io due to greater extant documentation. In this regard, we will analyse the election of the combatants, the main contribution of the town in I4IO, their permanence in the campaign or their behaviour, in addition to the theoretical time of departure and the itinerary followed. We will also study fiscal and treasury issues which permitted the mobilisation and the displacement of a large number of combatants and their impact on Paredes de Nava's finances: exacting extraordinary taxes, possible loans, and the lack of income. Furthermore, we will briefly examine news concerning the progress of the war that arrived to Paredes, as well as the council's expenses on festivities to celebrate the Castilian victory.

\section{Keywords}

Paredes de Nava; Military Campaign; Setenil; Antequera; Infante Fernando; Fifteenth Century; Crossbowmen; Spearmen. 


\section{INTRODUCCIÓN}

El presente trabajo pretende completar el gran vacío existente sobre las aportaciones de los concejos castellanos a las campañas militares contra el reino nazarí a comienzos del siglo xv. Conocemos una mínima parte, sobre todo del ámbito geográfico de Andalucía occidental y cercano a la frontera entre Castilla y Granada. En ese sentido destacan las ayudas de Sevilla, Córdoba o Jerez de la Frontera, sin duda, las bases logísticas más importantes. Las contribuciones de Sevilla las conocemos por la obra Archivo Municipal de Sevilla. Inventario de los papeles del Mayordomazgo del siglo XV (I4OI-I4I6), vol. $\mathrm{I}^{2}$, por «Un ajuste de cuentas del alcabalero mayor de Sevilla Pedro Ortiz (I420)» ${ }^{3}$ y, en menor medida y basado en ese documento, por el artículo «Una nueva estrategia para una vieja guerra. La preparación en Sevilla de la campaña de Antequera (I4IO)»`4 La capacidad militar de Sevilla y su Tierra previa a estas campañas, en concreto de I405, la conocemos por Las milicias de Sevilla ${ }^{5}$ y para la década de los años treinta del siglo xv por «Las milicias concejiles y su actuación exterior: Sevilla y la guerra de Granada (I430I439) $»^{6}$. Córdoba, que sepamos, no cuenta con ningún estudio al respecto, salvo las referencias que proporcionan las crónicas del reinado de Juan Il y las que basadas en ellas se encuentran en alguna monografía reciente ${ }^{7}$. Por su parte, Jerez de la Frontera ha sido objeto de un breve estudio, que hice yo mismo, titulado Las aportaciones de Jerez de la Frontera a la campaña de Antequera. Colección documental de las Actas Capitulares, publicado en $20 \mathrm{II}^{8}$. También el profesor Abellán se ha ocupado de esta última población al incluir diversos documentos en el Diplomatario del Reino de Granada. Documentos de Juan II de Castilla (I407-I454) del Archivo Municipal de Jerez de la Frontera ${ }^{9}$ y en artículos como «La presencia de Jerez de la Frontera en la

2. Collantes de Terán Delorme, Francisco: Archivo Municipal de Sevilla. Inventario de los papeles del Mayordomazgo del siglo XV (1401-1416), vol. I, Sevilla, Ayuntamiento de Sevilla, 1972.

3. Villaplana, María Asunción: «Un ajuste de cuentas del alcabalero mayor de Sevilla Pedro Ortiz (1420)», Historia. Instituciones. Documentos, I (1974), pp. 417-501.

4. Montes Romero-CAMACHO, Isabel: «Una nueva estrategia para una vieja guerra. La preparación en Sevilla de la campaña de Antequera (1410)», Historia. Instituciones. Documentos, 36 (2009), pp. 269-312.

5. Tenorio Cerero, Nicolás: «Las milicias de Sevilla», Revista de Archivos, Bibliotecas y Museos, $3^{\mathrm{a}}$ época, XVII (1907), pp. 222-263. Publicado con el título Las milicias de Sevilla, en Tres obras sobre la Sevilla del siglo XIV, Introducción y selección de textos de Deborah Kirschberg \& Francisco García Fitz, Sevilla, Ayuntamiento de Sevilla ICAS, 2009, pp. 6-44.

6. SÁnchez SAus, Rafael: «Las milicias concejiles y su actuación exterior: Sevilla y la guerra de Granada (14301439)», En la España Medieval. La ciudad hispánica durante los siglos XIII al XVI (III) (1987), pp. 393-418.

7. González SánCHEZ, Santiago: Los recursos militares de la monarquía castellana a comienzos del siglo xv. Las campañas militares del infante don Fernando: Setenil y Antequera (1407-1410), Madrid, Comité Español de Ciencias Históricas-Dykinson, 2016.

8. Como figura en el título de este libro la documentación utilizada pertenece a la sección Actas Capitulares del concejo xericense, correspondiente al período comprendido entre el 8 de enero y el 26 de julio de 1410. Dicha documentación nos permite entrever las exigencias militares de la monarquía castellana, a través de las misivas que el infante-regente don Fernando dirige a Jerez de la Frontera, así como la capacidad y disponibilidad de ese concejo para abastecer al ejército castellano de hombres, animales, provisiones y pertrechos de todo tipo.

9. AbelLán Pérez, Juan: Diplomatario del Reino de Granada. Documentos de Juan II de Castilla (1407-1454) del Archivo Municipal de Jerez de la Frontera, en Monumenta Regni Granatensis Historica. Diplomata, Granada, Editorial Universidad de Granada, 2011. 
conquista de Antequera ${ }^{\mathrm{IO}} \mathrm{y}$ «Jerez y la frontera occidental castellano-granadina en vísperas de la conquista de Antequera»" ${ }^{\mathrm{II}}$. Cuantitativamente menores, aunque sin duda importantes, serían las aportaciones de otros concejos andaluces como Écija ${ }^{\mathrm{I} 2}$, de los que ignoramos casi todo.

Otros ámbitos de la Corona de Castilla también cuentan con alguna escasa aportación bibliográfica, como la que hace Menjot para Murcia con «El peso de la guerra en la economía murciana: el ejemplo de la campaña de I407-I408 contra Granada» ${ }^{13}$. No obstante lo anterior, desconocemos casi todo lo relativo a esta cuestión y referido a otras zonas del reino ${ }^{14}$, salvo Villalón de Campos ${ }^{15}$ y referencias aisladas a poblaciones como Bonilla, Turégano o Santander. Las dos primeras como proveedoras de piezas de madera con las que fabricar distintas máquinas necesarias para el asedio a Antequera -bastidas, escala- y la tercera como receptora y distribuidora de grano con destino al ámbito fronterizo con el reino de Granada y, casi con toda certeza, al real castellano.

Por eso, es obvia la importancia de Paredes de Nava al ser una villa de señorío ${ }^{\mathrm{I} 6}$ y al disponer de una numerosa documentación en su archivo municipal, correspondiente

10. Abellán Pérez, Juan: «La presencia de Jerez de la Frontera en la conquista de Antequera», Estudios sobre Patrimonio, Cultura y Ciencias Medievales, 15 (2013), pp. 19-36.

11. AbelLán Pérez, Juan: «Jerez y la frontera occidental castellano-granadina en vísperas de la conquista de Antequera», Estudios de Frontera 9. Economía, derecho y sociedad en la frontera. Homenaje a Emilio Molina López, Francisco Toro Ceballos y José Rodríguez Molina (Coordinadores), Alcalá la Real, Diputación Provincial de Jaén, 2014, pp. 4354. Estos dos trabajos del profesor Abellán están recogidos en Estudios de Jerez y la frontera occidental granadina (Siglo $x v$ ), Libros de bolsillo EPCCM, 2, Disponible en la web https://www.librosepccm.com/libros-de-bolsillo/. En concreto en las páginas 31-48 y 49-82, respectivamente.

12. Sanz Fuentes, María Josefa: Colección diplomática del concejo de Écija (1263-1474), vol. IV, Sevilla, 1976.

13. Menjot, Denis: «El peso de la guerra en la economía murciana: el ejemplo de la campaña de 1407-1408 contra Granada», Fiscalidad y sociedad. Los murcianos y el impuesto en la Baja Edad Media, Murcia, Academia Alfonso X el Sabio, 1986, pp. 139-180.

14. Referido al siglo xIv y que en buena medida podemos extrapolar al siglo xv, el profesor García Fitz pone de manifiesto el desconocimiento existente sobre la potencialidad militar de las ciudades que «... se pondría de manifiesto con mayor claridad si se estudiara de una manera más detallada su participación directa en todos los conflictos que jalonan el siglo». García FITZ, Francisco: «' Las guerras de cada día '. En la Castilla del siglo xIV», Edad Media. Revista de Historia, 8 (2007a), p. 159.

15. Martínez Sopena, Pascual: «La conquête d'Antequera (1410). Réflexions sur la perception de la guerre dans la Castille du bas Moyen Âge», Diane de Chamboduc de Saint Pulgent, Marie Dejoux (ed.), La Fabrique des sociétés médiévales méditerranéennes. Les Moyen Âge de François Menant, Paris, Éditions de la Sorbonne, 2018, pp. 479-488.

16. Enrique III confirmaría a su hermano, con fecha 12 de octubre de 1404 , el trueque que hizo en 1400 con don Pedro Enríquez, conde de Trastámara, por el que don Fernando incorporaba a sus dominios la villa de Paredes de Nava. La confirmación de Enrique III la reiteró Juan II el 11 de julio de 1408 en Alcalá de Henares. Archivo General de Simancas, (AGS), Pat. Real, carp. 58, n. ${ }^{\circ}$ 99, y Biblioteca Zabálburu, (BZ), Miró, carp. 5, n. ${ }^{\circ} 61$. La trayectoria de Paredes de Nava entre los siglos XIII y comienzos del XV se contiene en MARTín CEA, Juan Carlos: El mundo rural castellano a fines de la Edad Media. El ejemplo de Paredes de Nava en el siglo xv, Valladolid, Junta de Castilla y León, 1991, pp. 37-48. Véanse, por ejemplo, Mitre Fernández, Emilio: «Un apunte sobre Don Fernando de Antequera y el señorío de Paredes de Nava», Estudios en homenaje a don Claudio Sánchez-Albornoz en sus 90 años. Anexos de Cuadernos de Historia de España, vol. IV (1986), pp. 283-288. Y del mismo «Implantación señorial y resistencia al régimen señorial en tierras de Palencia en la época Trastámara», Actas del I Congreso de Historia de Palencia. Tomo II. Fuentes documentales y Edad Media, Palencia, Diputación Provincial de Palencia, 1987, p. 311. Así como los trabajos de MuÑoz GómEz, Víctor: «La adquisición de dominios señoriales en la Castilla bajomedieval. Fernando de Antequera y Paredes de Nava (1380-1408)», Actas del III Simposio Internacional de Jóvenes Medievalistas Lorca 2006, Juan Francisco JIMÉNEz ALCÁZAR, Juan Leonardo SOLER Milla y Jorge Ortuño Molina (Eds. científicos), Murcia, Universidad de Murcia-Ayto. Lorca-Real Academia Alfonso X el Sabio-Fundación Cajamurcia-Lorcatur-SEEM, 2008, p. 124, «El concejo de Peñafiel. Gobierno y sociedad en una villa vallisoletana en la Edad Media», Miscelánea Medieval Murciana, XXXIV (2010), pp. 71-81, del mismo autor El poder 
a la sección Cuentas de Propios $^{17}$. Este fondo abarca desde I37I hasta la actualidad y, por lo que a nosotros respecta, además de su continuidad, contiene los años de las campañas castellanas contra el reino de Granada a comienzos del siglo xv. Algunas características de la documentación manejada son que está escrita en letra gótica cortesana y precortesana y que se presenta en pliegos horadados en la parte superior unidos mediante cordel, hoy desparecido. El estado de conservación es bueno en general, si bien algunos pliegos están carcomidos o presentan manchas que hacen ilegible o dificultan la transcripción de las letras. Desde un punto de vista organizativo las cuentas, por ejemplo las de I4IO, se ordenan con números arábigos que distintos archiveros del siglo xx realizaron a lápiz, por una de las caras del papel. Los registros contables corresponden a los dos procuradores de cada mandato -por ejemplo en I4Io García González Berruguete y Juan Fernández Bueno-, que entregaban cuentas distintas y complementarias, además de las de procuraciones especiales, como algún viaje, y las cuentas del escribano del concejo - caso también de I4IO-.

El tratamiento de la información aportada, de la que se han recopilado aproximadamente quince noticias referidas a 1407 , una a 1408 , veinticinco a I409, algo más de noventa a I4IO y entre veinticinco y treinta a I4II, se ha hecho atendiendo a un criterio cronológico, siempre que ha sido posible, pues muchos documentos carecen de data y contrastando las cuentas de los distintos oficiales concejiles, al igual que los pagos parciales o las demoras en satisfacerlos, con crónicas y ejemplos de otras poblaciones. El uso de documentos inéditos, abundantes en este caso, nos ha llevado a plantear preguntas de las que han surgido nuevos interrogantes, a los que en varias ocasiones no se ha podido dar una respuesta satisfactoria, por lo que no hay más que reconocer el carácter limitado de las explicaciones dadas. Por otro lado, la documentación estudiada pone de manifiesto la imbricación entre guerra y fiscalidad, considerándose un elemento de gran importancia en el fortalecimiento del poder regio y, por lo que respecta al caso analizado, al del poder señorial. No obstante, la proyección señorial y sus vínculos con la política y con la sociedad, como las relaciones de poder o las redes clientelares, en distintas escalas y niveles, en las que el infante don Fernando estaba comprendido, no se abordan, entre otras razones porque cargarían el trabajo y no contribuirían a esclarecer el objetivo que persigue este artículo.

\footnotetext{
señorial de Fernando "el de Antequera» y los de su Casa. Señorío, redes clientelares y sociedad feudal en Castilla durante la Baja Edad Media, Madrid, CSIC, 2018, pp. 155-158. Y también GonzÁlez SÁNCHEZ, Santiago: Fernando I, regente de Castilla y rey de Aragón (1407-1416), Gijón, Trea, 2012, p. 213.

17. Sobre esta serie documental véase Peral, Santiago, Robles, José A, CARLón, Concepción y Ausín, Margarita: «Las Cuentas de Propios del Archivo de Paredes de Nava y su ordenación», Publicaciones de la Institución Tello Téllez de Meneses, 64 (1993), pp. 611-619. También ha destacado su importancia, entre otras razones por ser de las primeras muestras contables en el reino de Castilla, a finales del siglo XIV, en concreto de 1386, FUENTE PÉREZ, María Jesús: «Los inicios de la contabilidad municipal en Castilla. Paredes de Nava (1386-1396)», Espacio, Tiempo y Forma, Serie III, Historia Medieval, 11 (1998), pp. 61-83. Sobre otras como la de Cartas Reales véase TERESA LEóN, Tomás: «De nuestros archivos. Archivo Municipal de Paredes de Nava», Publicaciones de la Institución Tello Téllez de Meneses, 8 (1952), pp. 5-26.
} 
La decisión de acometer este estudio no responde a unas características particulares de Paredes de Nava que lo diferenciarían de lo que ocurrió en otras poblaciones de Castilla, lo interesante es que es prácticamente la única población ${ }^{18}$ que dispone de una documentación contable referida a este hecho de armas, la toma de Antequera.

En otro orden de cosas, Paredes de Nava forma parte desde un punto de vista geológico de la depresión del Duero, en la Submeseta Septentrional, siendo los materiales predominantes de su suelo las arenas, arcillas, margas y calizas. En este territorio podemos diferenciar dos zonas, una zona de campiña al Suroeste y otra de páramo al Noreste. Su clima es propio de un dominio Mediterráneo continentalizado, caracterizado por dos estaciones, una invernal muy larga y una estival muy corta, solo los meses de julio y de agosto, siendo muy escasas las precipitaciones.

Atendiendo a la demografía Paredes de Nava a comienzos del siglo xv era la villa más poblada de Tierra de Campos y en concreto de la zona oriental, entre otras razones por los numerosos núcleos que englobaba -al menos doce-, llegando incluso a superar en número de habitantes en algunos momentos a la propia Palencia. En los siglos xv y xvı Paredes estuvo entre las quince localidades más pobladas de Castilla ${ }^{\mathrm{I}}$.

La evolución histórica de Paredes de Nava previa a nuestra época de estudio osciló entre su pertenencia al realengo, por ejemplo durante el reinado de Sancho IV y su integración en distintos señoríos, como el de la Orden de Calatrava. Siendo a partir del reinado de Enrique II cuando Paredes de Nava pasó a integrarse en el patrimonio de distintos linajes de la nobleza laica, como el de los Enríquez de quien pasó al infante don Fernando y más tarde, por concesión de Juan Il, a la familia Manríquez de Lara, que se titularon condes de Paredes.

Desde un punto de vista institucional y para nuestra época de estudio el concejo de Paredes de Nava estaba regido por dos alcaldes y ocho hombres buenos, auxiliados por un escribano y dos procuradores. Y a efectos administrativos, la villa estaba dividida en ocho barrios, el más importante de los cuales, desde un punto de vista fiscal, era el de la Fuente.

18. Las excepciones, con matices, serían Sevilla, Jerez de la Frontera y Villalón de Campos; otras poblaciones no cuentan con apuntes ni tan extensos ni tan pormenorizados.

19. Para los años que aquí nos interesan sabemos que Paredes de Nava contaba con 840 vecinos en 1409 y con 763,5 en 1410, que en ambos casos corresponden a igual número de fumazgos. FuENTE PÉrez, María Jesús: «Fuegos fiscales y fuegos reales. Paredes de Nava en el siglo XV», En la España Medieval, 16 (1993), pp. 87 y 93. Descenso que Martín Cea, Juan Carlos: op. cit., p. 36, explica en función de las exenciones que se les aplicaron a los vecinos que fueron con el infante a conquistar la villa de Antequera. Y que Fuente Pérez matiza con que solo se vieron afectados 28 vecinos, mientras que el descenso del número de fumazgos es de 76,5 . Los datos del número de vecinos que esta autora proporciona los toma REGLERO DE LA FUENTE, Carlos: «El poblamiento del Noreste de la cuenca del Duero en el siglo XV», Hispania, LV/ 190 (1995), nota 22, p. 432. 


\section{EL CONCELO DE PAREDES DE NAVA Y LA CAMPANA DE 1407}

El concejo de Paredes de Nava, como otros de la Corona de Castilla de realengo o de señorío, contribuyó de diversas maneras a las campañas militares dirigidas contra el reino nazarí de Granada durante la minoría de Juan II de Castilla. Sus aportaciones a la campaña de 1407 tuvieron tres aspectos: aprovisionamiento de víveres, financiación económica y transporte.

Casi con total certeza Paredes de Nava contribuyó al avituallamiento de las tropas castellanas en la campaña de 1407 con el envío de trigo, en concreto ochenta cargas, al puerto de Santander ${ }^{20}$, sin duda para su traslado al Sur de la Península y con toda probabilidad al de Sevilla ${ }^{21}$. El transporte del trigo hacia Santander es muy probable que se hiciera en acémilas, entre otras razones por la dificultad que imponían los caminos y por la fiabilidad y resistencia de esos animales. Desconocemos igualmente la duración del viaje hasta Santander y, lo que quizá sea más importante, el peso de la carga ${ }^{22} \mathrm{y}$, por consiguiente, el total de lo aportado.

La financiación de la campaña de 1407 supuso un importante desembolso económico para los habitantes de Paredes. Las peticiones exactivas llegaron por tres vías, la monarquía a través del cobro del servicio con el pedido y monedas, el señor mediante el préstamo y la Iglesia a través del diezmo del que derivaba una parte para la Corona. Respecto al pedido, la Corona se limitaba a indicar el importe global, correspondiendo su recaudación a los concejos, para lo que se tenía en cuenta el número de vecinos y la riqueza estimada. El pedido se convirtió en parte de los ingresos extraordinarios de la Hacienda real que las Cortes concedían desde finales del siglo $\mathrm{XIV}^{23}$. Por su parte, las Cortes otorgaban las monedas también con el mismo carácter, sin embargo, a diferencia del pedido, las monedas -unidades de cobro- que variaban según la ocasión, se arrendaban a particulares y de su pago estaban exentos desde territorios como Vizcaya, hasta

20. El papel de Santander como receptor de envíos de grano procedentes del interior de Castilla, también se produjo en la campaña de 1410. Véase GonZÁlez SÁnCHEZ, Santiago: Los recursos militares..., p. 250.

21. Archivo Municipal Paredes de Nava, (AMPdN), Cuentas de Propios, (CP), 238/9, carp. 8, f. $39 \mathrm{v}$.

22. Ladero Quesada, Miguel Ángel: «Baja Edad Media», Historia Militar de España, Dirigida por Hugo O' DonnelL, Edad Media, Tomo II, Miguel Ângel Ladero Quesada (Coordinador), Madrid, Ministerio de Defensa-Laberinto, 2010, p. 292, recoge que por mula o carga mayor eran (2,5 fanegas, unos 110 kilos de cereal) y que por asno o carga menor eran ( 2 fanegas, unos 89 kilos). Si aplicamos el primer criterio tenemos que se enviaron 8.800 kilos de cereal y si lo hacemos con el segundo 7.120 kilos.

23. Entre la numerosa bibliografía existente véanse ROMERO ROMERO, Francisco José: Sevilla y los pedidos de Cortes en el siglo XV, Sevilla, Ayuntamiento de Sevilla ICAS, 1997; LADERO QUESADA, Miguel Ángel: Fiscalidad y poder real en Castilla (1252-1369), Madrid, Real Academia de la Historia, 2011, p. 52; ORTEGO RICO, Pablo: «Pedido» regio y repartimientos en Castilla: una aproximación a partir del ejemplo del Arzobispado de Toledo (1399-1476)», Baetica, 3637 (2014-2015), pp. 119-156 y TRIANO MILÁN, José Manuel: La llamada del rey y el auxilio del reino. Del pedido regio a las contribuciones de la Santa Hermandad (1406-1498), Sevilla, Universidad de Sevilla, 2018, pp. 41-129, en especial, donde trata sobre la definición, bases institucionales, evolución, consolidación, relevancia del ingreso, gasto del pedido, etc. 
los grupos privilegiados y cupos de excusados en algunos lugares del reino ${ }^{24}$. La mayor parte de los servicios que las Cortes de la minoría de Juan II concedieron fueron por motivos bélicos, para la guerra contra los granadinos doscientos dieciocho millones y dieciocho para construir una armada con la que ayudar a Francia. Respecto al préstamo al señor, el infante don Fernando, al margen de las connotaciones de vasallaje que se pueden inferir está la frecuencia con que el regente castellano, después rey de Aragón, recurre a este tipo de práctica, bien por cuestiones familiares o políticas, a pesar de estar excepcionalmente dotado $^{25}$. La tercera vía de exacción fue el diezmo que la Iglesia percibía en Castilla, las tercias o tercias de fábrica ${ }^{26}$-las dos novenas partes del diezmo- ${ }^{27}$ se debían emplear para combatir al islam. Por su propia naturaleza las tercias fueron un tributo que se encuadrarían entre los extraordinarios, al menos esa era la intención por parte del papado. Pero, de forma simultánea, la monarquía de manera evidente durante la minoría de Juan Il, tratará de que pase a ser ordinario, como lo demostraría el hecho de que se arrendasen junto con las alcabalas $^{28}$. Los regentes solicitaron y obtuvieron del pontífice Benedicto XIII, en I407, su concesión por tres años más ${ }^{29}$. Detrás de esta concesión se esconden las aspiraciones del pontífice, deseoso de contar con el apoyo castellano en sus pretensiones y, por descontado, con el del regente castellano, con el que a través de terceros, como el obispo Climent Sapera, mantenía una estrecha relación que se concretará años después con su respaldo al trono de la Corona de Aragón. Además, estos pagos que pasamos a detallar nos ponen sobre la pista de los importantes ingresos señoriales que el infante percibía y de la extracción de renta procedente de la Hacienda regia y de la fiscalidad de la Iglesia, alguna de las cuales, como las tercias se convirtieron en hereditarios ${ }^{30}$.

24. Ladero Quesada, Miguel Ángel: «Fiscalidad regia y génesis del Estado en la Corona de Castilla (1252-1504)», Espacio, Tiempo y Forma, Serie III, Historia Medieval, 4 (1991), pp. 95-135.

25. Aunque referidas a su etapa como rey de Aragón véase GonZÁLEZ SÁNCHEZ, Santiago: Fernando I..., pp. 222-223.

26. Nieto SoriA, José Manuel: Iglesia y génesis del Estado Moderno en Castilla (1369-1480), Madrid, Universidad Complutense, 1993, pp. 318-319.

27. O como sabemos que ocurría en el arzobispado toledano, el 22,22 por ciento del total era lo que le correspondía al rey en el sistema de reparto. GUADALUPE BERAZA, María Luisa: Diezmos de la sede toledana y rentas de la mesa arzobispal (Siglo xv), Salamanca, Universidad de Salamanca, 1972, pp. 15, 17, 18 y 19. RodríGuez MolinA, José Luis: «El diezmo eclesiástico en el valle del Guadalquivir, su utilidad para el estudio de la Historia Económica», Actas del / Congreso de Historia de Andalucía, vol. I, Córdoba, Publicaciones del Monte de Piedad y Caja de Ahorros de Córdoba, 1978, p. 432, especifica que se detraía del Tercio de fábrica, es decir, el dedicado a la construcción, reparación y otros gastos del templo parroquial que, al descontar los 2/9 que iban a la cámara regia quedó reducido a 1/9.

28. Ladero Quesada, Miguel Ángel: La Hacienda Real de Castilla en el siglo XV, La Laguna, Universidad de La Laguna, 1973, p. 89. Su transformación en ingreso ordinario de la fiscalidad regia, en contra de los criterios que dieron lugar a su creación, lo señala NIETO SORIA, José Manuel: op. cit., p. 317.

29. Archivo Vaticano, (AV), Reg. Avin., vol. 328, fols. 14r-15V, citado por ViLLARRoel GonZÁLEZ, Óscar: Las relaciones monarquía-Iglesia en época de Juan II de Castilla (1406-1454), vol. I, Madrid, Universidad Complutense, 2007, p. 144. Hay varias noticias de su percepción en Murcia en 1408. Archivo Municipal de Murcia, (AMM), Actas Capitulares (AC), (1408 marzo 12), fol. 147v, donde Lope García de Toledo presenta ante el concejo una carta del rey en la que mandaba hacer el bizcocho de las tercias que él tenia en la ciudad. Y otro AMM., AC, (1408 diciembre 20), fol. 128v, por el que el rey ordena que los terceros de la cebada de Murcia la llevasen de las tercias a la ciudad de Cartagena.

30. Remitimos para estas cuestiones al trabajo de MuÑoz GómEz, Víctor: El poder señorial..., pp. 350-397, en especial. 
Así pues y desde un punto de vista fiscal los paredeños satisficieron 156.000 maravedíes a través de las dieciocho monedas y del pedido que el rey ordenó en $1407^{3 \mathrm{I}} \mathrm{y}$, además, el infante don Fernando, a través del obispo de Coria, el dominico fray García de Castronuño, su capellán ${ }^{32}$, solicitó al concejo un préstamo de 60000 maravedíes ${ }^{33}$, del que intuimos su finalidad y del que no sabemos nada más. Precisamente y con ese destino -la campaña militar- el pontífice Benedicto XIII concedió al infante las tercias de la Iglesia castellana ${ }^{34}$, de las que ignoramos su cuantía.

La tercera aportación de Paredes de Nava a esta primera campaña militar castellana de comienzos del siglo xv tiene que ver con los medios de transporte, en concreto carros con sus correspondientes bueyes y hombres que los condujeran. Paredes contribuyó con diez carreteros, diez carros y diez pares de bueyes por un tiempo de dos meses $^{35}$, que es muy probable que estuviesen presentes en la gran operación de transporte que se hizo tras el asedio y conquista de Zahara ${ }^{36} \mathrm{o}$, en cualquier caso, con motivo las necesidades derivadas del posterior asedio a Setenil, aunque no haya ninguna mención ni documental ni cronística al respecto. Previo al envío de estos carreteros, carros y bueyes existió un proceso de selección en el que:

... fueron apresçiados los díes pares de buey con sus carros e atuendo quel dicho sennor rey mandó levar a la guerra de los moros con el rrecabdador del rrey, que fueron presçiados sobre juramento que fesieron Alfón García e Ferrando Díes procuradores, el qual testimonio di a Juan Martínes rrecabdador signado de mi signo ${ }^{37}$.

Sobre el pago a los carreteros de Paredes contamos con diversos testimonios ${ }^{38}$, no obstante lo relevante es la cuantía total que se elevó a «... catorse mill e veynte çinco mrs que montó los dies carros e buey e el salario de los dies carreteros que fueron a serviçio de nuestro sennor el rrey» ${ }^{39}$. Así pues, cada carretero percibió del concejo I 400 maravedíes, en diversos pagos, por los dos meses de servicio, a razón de 700 maravedíes mensuales. Los díez carreteros «... que fueron al real de los moros» dieron carta de pago en fecha indeterminada de 1408 reconociendo que el concejo de Paredes de Nava les había satisfecho todo su salario ${ }^{40}$. De sus nombres solo nos han llegado tres, los de Juan Magarço, Toribio yerno de Juan Grande y Alfón Cabeçudo ${ }^{41}$.

31. AMPdN., CP., 238/9, carp. 8, f. 13 .

32. GonZÁlez SÁNCHEZ, Santiago: «Los obispos castellanos en los inicios del siglo xv (1407-1420)», Estudios sobre Patrimonio, Cultura y Ciencias Medievales, 15 (2013), pp. 187-214.

33. AMPdN., CP., 238/9, carp. 8, f. 23 r.

34. AMPdN., CP., 238/9, carp. 8, f. 31r.

35. AMPdN., CP., 238/9, carp. 8, ff. 31v, $40 \mathrm{ov}$ y $4 \mathrm{lv}$.

36. PéRez de GuzMÁn, Fernán: Crónica del serenísimo príncipe don Juan, segundo rey deste nombre en Castilla y León, escrita por el noble y muy prudente caballero Fernán Pérez de Guzmán, Señor de Batres, del su Consejo, Biblioteca de Autores Españoles, Ordenada por don Cayetano RoselL, LXVIII/ II, Madrid, 1953, pp. 292-293.

37. AMPdN., CP., 238/9, carp. 8, f. $40 \mathrm{v}$.

38. Llama la atención que todos ellos recojan la expresión «[...] que fueron» cuando se trata de la satisfacción de algún pago aunque, como sabemos por otros casos parecidos, percibían una determinada cantidad antes de salir de viaje.

39. AMPdN., CP., 238/9, carp. 8, f. $41 \mathrm{v}$.

40. AMPdN., CP., 238/10, carp. 9, f. 39r.

41. AMPdN., CP., 238/9, carp. 8, f. $29 \vee$ y 31 r. 


\section{LOS PREPARATIVOS PARA LA CAMPAÑA DE 1410}

\subsection{EL AÑO 1409}

La campaña militar de I4Io comenzó a prepararse con bastante antelación ${ }^{42}$. Desde una óptica económica hay que tener en cuenta una estrategia que pasa por la necesidad de acumulación previa, tanto de dinero como de vituallas o de armamento. Desde un punto de vista demográfico, aún a pesar de estar bajo un régimen demográfico antiguo, el crecimiento vegetativo de Castilla era positivo desde hacía varias décadas, por lo que la provisión de hombres estaba asegurada. Desde una óptica político-ideológica se recurre a motivos de carácter religioso: el servicio de Dios y la destrucción de los enemigos de la fe; de índole moral: el concepto de honra, aunque de carácter individual, don Fernando lo hará extensivo al conjunto del reino «... por onrra destos reynos he tomado en mi toda la carga de la guerra de los moros» ${ }^{43} \mathrm{o}$ a razones político-estratégicas «... porque su corona e honra e su serviçio de sus Reinos sea guardado e llevado adelante, con mayor acreçentamiento de señoríos»44; si el sultán granadino quería treguas que le diese las parias y prestase al rey de Castilla el vasallaje que le debía ${ }^{45}$. Otro argumento es culpabilizar a los reyes granadinos de no satisfacer los deseos castellanos con el pago de parias y con la devolución de cautivos y de propiedades que les habían arrebatado ${ }^{46}$. Tampoco deben olvidarse otros aspectos que pueden entreverse en la decisión castellana y que, por supuesto, no se hicieron nunca explícitos, son el de rivalidad o competencia, sobre todo tras la toma de Ceuta por los portugueses en I4I5 y las aspiraciones personales del infante don Fernando ${ }^{47}$.

El primer testimonio que tenemos al respecto referido a Paredes de Nava es la convocatoria de un alarde, siendo los alardes, junto a los padrones fiscales, las principales fuentes de conocimiento del estado de la población. En líneas generales, conocemos una mínima parte de los alardes ordinarios y extraordinarios ${ }^{48}$ que se hicieron. Los alardes, salvo casos fijados por las ordenanzas municipales en las que

42. GonzÁlez SÁnChez, Santiago: Los recursos militares..., 2016.

43. AMM., Cartulario Real 1391-1412, fol. 106r, publicado por VilapLANA GISBERT, María Victoria J.: Documentos de la minoría de Juan II. La Regencia de Don Fernando de Antequera, CODOM, vol. XV, Murcia, Academia Alfonso X el Sabio, 1993, n. ${ }^{\circ}$ CXXIV, pp. 251-252.

44. García de Santa María, Álvar: Crónica de Juan I/ de Castilla, Edición de Juan de Mata Carriazo y Arroquia, Madrid, Real Academia de la Historia, 1982, pp. 13-14.

45. García de Santa María, Álvar: op. cit., pp. 269 y 333.

46. García de Santa María, Álvar: op. cit., p. 333.

47. Estos ejemplos y aspectos en GonZÁlez SÁNCHEZ, Santiago: Los recursos militares..., pp. 113-119.

48. TORRES FonTES, Juan: «La caballería de alarde murciana en el siglo Xv», Anuario de Historia del Derecho Español, XXXVIII (1968), pp. 37-40, ha descrito cómo se efectuaban los alardes en la ciudad de Murcia. En una fecha concreta, ya fijada, bajo la presidencia de corregidor o asistente de turno o de uno de los alcaldes ordinarios, asistidos por un escribano y tres o cuatro testigos, se hacía por parroquias, a una hora señalada, en la que el escribano tomaba nota y hacía constar datos de si era caballo, potro o yegüa, así como la calidad del caballo, y en tal caso los motivos por los que se le recusaba -falta de edad, haber sido utilizados en acarreo, labranza o carga-. 
tenían fechas establecidas, se convocaban con la suficiente antelación para que cada uno pudiera ir provisto del armamento y caballo, en los casos pertinentes, que le correspondían por su capacidad económica. Los alardes afectaban a toda la población comprendida en edad militar, es decir, la que tenía entre dieciséis y sesenta años.

Así, y por lo que respecta a Paredes de Nava, conocemos que a comienzos de 1409 el concejo enviaba un hombre a Peñafiel, villa del regente castellano ${ }^{49}$, para «... saber de qué manera fesieron los alardes que nuestro sennor el infant mandó faser» ${ }^{50}$. El primero de los varios alardes que se hicieron en 1409 se realizó el martes 26 de febrero $^{5 \mathrm{I}}$, aunque parece ser que el infante ordenó que se hiciese el I de marzo ${ }^{52}$. Alarde que el concejo trató de preparar bien por ciertas carencias. De ahí que enviase a:

Ferrand García Marinero et a lohn García fijo de Tomás Ferándes clérigo por veynte et çinco dosenas de viratones e pasadores que me dieron por cuenta que costara la dosena a dose mrs con la costa que fesieron en el camino ellos et las bestias asy que monta en estas veynte et çinco dosenas tresientos mrs et estas veynte et çinco dosenas quedaron de vender a Ferrand García Marynero et a lohn García de çiento et treynta dosenas de pasadores que traxieron de Burgos que el conçejo les auja mandado que fuesen a Burgos et traxiesen los más pasadores que podiesen auer para el alarde que nuestro sennor el infant mandó faser [...] et las que no podiesen vender que las resçebría el conçejo $0^{53}$.

\section{No obstante el:}

Domingo veynte et siete días de otubre veno Diego Rrodrigo Çapata a esta villa de Paredes por carta et mandado de nuestro sennor el infant et fiso faser alardes et nombró a çiertos omnes para que estén aperçebydos de quel sennor infant los enbiare llamar para la guerra de los moros et estudo el dicho Diego Rrodrígues Çapata en esta villa quatro días ${ }^{54}$.

Alarde del que se hizo copia por duplicado ${ }^{55} \mathrm{y}$ al que «... algunos vesinos desta villa... no salieron ${ }^{56}$. Este mismo 27 de octubre se reunió el concejo para tratar sobre los alardes y sobre «... manferir çiertos omnes que fuesen al rreal por mandado del infant $»^{57}$. Es muy probable que Rodríguez Zapata escogiese en este alarde a veinticinco ballesteros y a cuarenta lanceros ${ }^{58}$, razón por la que el concejo de Paredes envío un testigo a Saldaña, el jueves 3i de octubre, para conocer el

49. La concesión en López de Ayala, Pero: Crónicas. Crónica del rey don Juan. Primero de Castilla y de León, Edición, prólogo y notas de José Luis MARTín, Barcelona, Planeta, 1991, cap. IV, p. 661. MuÑoz GómEZ, Víctor: El poder señorial..., p. 129 y ss. Este autor se había ocupado de Peñafiel de forma general en «El concejo de Peñafiel...», pp. 71-81

50. AMPdN., CP., 238/11, carp. 10, f. 5 r.

51. AMPdN., CP., 238/11, carp. 10, f. 27r.

52. AMPdN., CP., 238/11, carp. 10, f. 6r.

53. AMPdN., CP., 238/11, carp. 10, f. 6r.

54. AMPdN., CP., 238/11, carp. 10, f. 14v.

55. «[...] que lo escriujó este Pero Cabrito dos veses». AMPdN., CP., 238/11, carp. 10, f. 14r. Por desgracia no conocemos ninguna copia que haya llegado hasta hoy.

56. AMPdN., CP., 238/11, carp. 10, f. 15 r.

57. AMPdN., CP., 238/11, carp. 10, f. 35r.

58. AMPdN., CP., 238/11, carp. 10, f. 44 v. 
número de lanceros y ballesteros que Diego Rodríguez Zapata había elegido en dicha localidad59.

En fechas cercanas, pues es del 8 de noviembre de I409, se hizo alarde en Villalón, que debería aportar veinticinco ballesteros y treinta y tres lanceros ${ }^{60}$. Por lo que es fácil deducir que otras villas del señorío de don Fernando en esta misma zona como Saldaña o Mayorga, por poner unos casos, estarían en las mismas circunstancias.

Otra demanda que don Fernando hizo a Paredes de Nava en I409 fue la de una elevada cantidad de dinero, cien mil maravedíes, cuyo fin, que en este caso se especifica, era «... para la guerra de los moros» ${ }^{6}$. Sin duda, la visita del señor de la villa el infante-corregente, de su mujer y de sus hijos a Paredes de $\mathrm{Nava}^{62}$ a comienzos de agosto de $1409^{63}$, estaba relacionada con los preparativos para la campaña de I4Io y facilitaría la percepción de tan importante cantidad, caso de que hubiera alguna resistencia ${ }^{64}$. Sin embargo, la reserva de las fuentes no vuelve a informarnos y dudamos de que se recaudara, entre otras razones porque no hay ninguna constancia documental al respecto.

\section{LA CAMPAÑA DE 1410}

La decisión de iniciar una campaña militar contra los granadinos se fue demorando por razones tan diversas como las necesidades económicas que conllevaba. Que se iniciara en I4Io tuvo mucho que ver con las aspiraciones personales de don Fernando, que supo servirse del aumento de los incidentes fronterizos y de las continuas alarmas de ataques granadinos que se sucedieron durante las treguas, y

59. AMPdN., CP., 238/11, carp. 10, f. 35v. En otro orden de cosas, conocemos que Saldaña y su tierra proporcionaron peones a la campaña de 1410, que Diego Rodríguez Zapata se encargó de escoger durante dos días. Véase al respecto AMPdN., CP., 238/12, carp. 11, f. 23r. La villa de Saldaña formaba parte de las posesiones del regente don Fernando y de su mujer doña Leonor. Las vicisitudes de ese señorío a partir de 1412 las detalla Franco SILVA, Alfonso: «El proceso de señorialización de las tierras de palentinas en la Baja Edad Media. El caso del Condado de Saldaña», Señores y señoríos (siglos XIV-XV), Jaén, Universidad de Jaén, 1997, pp. 195-215.

6o. Martínez Sopena, Pascual: op. cit., p. 486

61. AMPdN., CP., 238/11, carp. 10, f. 3v.

62. Véase, por ejemplo, Mitre FernándeZ, Emilio: «Un apunte sobre Don Fernando...», pp. 283-288.

63. Al menos estaría en la citada población el sábado 3 de agosto, como consta en AMPdN., CP., 238/11, carp. 10 , f. 10v. Algunas de las cosas que dispuso el concejo para su recibimiento y diversión se encuentran en AMPdN., CP., 238/11, carp. 10, f. 3v. Varios de los gastos ocasionados por esta visita, como limpieza, derechos percibidos por entrada, alojamiento de algunos servidores, en AMPdN., CP., 238/11, carp. 10, ff. 10v y 15r. También habría servido para imponer su autoridad, vetando portar armas a los vecinos de la villa que no fuesen oficiales de justicia del concejo, como da cuenta MUÑoz GómEZ, Víctor: «Bandos urbanos y pacificación señorial en la Castilla bajomedieval: Paredes de Nava y Fernando de Antequera (1400-1416)», Anuario de Estudios Medievales, 39/ 2 (2009), p. 692. El documento en cuestión es el siguiente AMPdN., CP., 238/11, carp. 10, f. 11v. Item pagué al trompeta del infant çinquenta mrs por mandado de Velasco Ferrándes et de Gonçalo Lópes et del doctor Cascales porque traxo la trompeta con el pregonero de la villa que ningún non fuese osado de traer armas, çinquenta mrs. (L).

64. Quiza no en este caso, pero en otros nos consta que al menos hubo demoras en satisfacer las elevadas exigencias fiscales, como también ocurrió en Villalón de Campos, Saldaña y Mayorga, de lo que da cuenta MARTínEZ SOPENA, Pascual: op. cit., pp. 485-486. 
de los respaldos que recabó de la Iglesia, de las Cortes y de la nobleza, en el ámbito interno. Y en el exterior de la actitud de los reinos cristianos peninsulares y de otros del entorno europeo occidental, así como de la inestabilidad en el trono granadino. Sin desdeñar todo el argumentario ideológico señalado con anterioridad.

\subsection{LA ELECCIÓN DE LOS COMBATIENTES}

El soberano podía exigir a sus súbditos hacer la guerra ${ }^{65}$, en ocasiones solicitaba un determinado número de hombres ${ }^{66}$, por lo que correspondía conocer la cantidad de gente disponible para llevarla a $\mathrm{cabo}^{67}$, por lo general a través de los padrones fiscales y de los alardes, de los que se ha dado cuenta. Además de a los caballeros, la militarización, y por consiguiente la disponibilidad de armas, afectaba a toda la población. Así, y por poner un ejemplo, en Ciudad Rodrigo los pecheros se dividían en tres niveles distintos según su aportación fiscal: de pecha completa, de media pecha y los exentos de pechar por carecer de hacienda. Los primeros estaban obligados a tener una ballesta de acero con doce pasadores y una espada; los de media pecha, un escudo y una espada, y los exentos por pobres, una lanza y un dardo o azagaya ${ }^{68}$.

Efectuados los alardes había que repartir, manferir -señalar- y tener preparada a la gente asignándose un determinado número a cada una de las poblaciones. Según la ordenanza del Consejo Real, que Enrique Ill hizo en Segovia en I406, era competencia de éste enviar las cartas de llamamiento ${ }^{69}$, aunque no hay constancia al respecto de que lo hiciera durante la minoría de Juan Il. Quien parece

65. La obligación de prestar el servicio militar es una de las cuestiones que se tratan en el artículo de Moxó y ORTIZ DE VILLAJOS, Salvador de: «El Derecho militar en la España cristiana Medieval», Revista Española de Derecho Militar, 12 (1961), pp. 9-59. Véanse también de LADERo QUESADA, Miguel Ángel: «La organización militar de la Corona de Castilla en la Baja Edad Media», Castillos medievales del Reino de León, León, Hullera Vasco-Leonesa, 1989, p. 13, y «Formación y funcionamiento de las huestes reales en Castilla durante el siglo Xv», La organización militar en los siglos xv y xvı. Actas de las II Jornadas Nacionales de Historia Militar, Málaga, Cátedra «General Castaños», 1993, p. 164. Así como de GARCíA FITZ, Francisco: «La organización militar en Castilla y León (siglos XI al XIII)», Conquistar y defender. Los recursos militares en la Edad Media Hispánica, en Revista de Historia Militar, año XLV, n. ${ }^{\circ}$ extraordinario, (2001), p. 66, y del mismo «La composición de los ejércitos medievales», La guerra en la Edad Media: XVII Semana de Estudios Medievales, Nájera, del 31 de julio al 4 de agosto de 2006, Blas CASADO QuinTANILLA y José Ignacio de la PEÑA DUARTE (ed.), Nájera, Instituto de Estudios Riojanos, 2007b, pp. 85-146.

66. Por ejemplo, las que en nombre de Enrique III hace su hermano, el infante don Fernando, en las Cortes de Toledo. GARCía de SANTA MARÍA, Álvar: Le parti inedite della «Crónica de Juan Il» di Álvar García de Santa María, Edizione critica, introduzione e note a cura di Donatella Ferro, Venezia, Consiglio Nazionale delle Richerche [Gruppo Studi d'Ispanistica], 1972, pp. 10-11 y del mismo autor Crónica..., p. 12.

67. Se trataba de evitar la desproporción entre los combatientes que se estimaban y la realidad pues, en ciertos casos como el de Sevilla, esta desproporción llevó a examinar las nóminas de francos en previsión de nuevas campañas. Pérez de GuzMán, Fernán: op. cit., p. 302.

68. Bernal Estévez, Ángel: «Las armas como concepto fiscal y de diferenciación social en la Baja Edad Media (Aplicación al caso de Ciudad Rodrigo)», Gladius. Etudes sur les armes anciennes, I'armament, l'art militaire et la vie culturelle en Orient et Occident. Primer Simposio Nacional sobre «Las armas en la Historia» (marzo 1983), Cáceres, 1988, p. 29.

69. Real Biblioteca de El Escorial. Mss. castellanos, Z II. 7, fols. 3b-8b, publicado por MARTínez MARINA, Francisco: Teoría de las Cortes o grandes juntas nacionales de los reinos de Castilla y León, ed. de José Manuel PÉrez Prendes, vol. III, Madrid, 1979, n. ${ }^{\circ}$ XXIV, pp. 1292-1299, y por Dıos, Salustiano de: «Ordenanzas del Consejo Real de Castilla (1385-1490)», 
que asumió esa función en nombre del monarca y en el suyo propio fue el infante don Fernando ${ }^{70}$. La elección de las tropas que el concejo tenía que enviar no era sencilla. Los escogidos tendrían que someterse a una inspección que determinaba si eran idóneos o no. La preparación de las tropas no implicaba, que sepamos, adiestramiento militar, ni individual ni colectivo. Creemos que bajo ese concepto se alude a su disposición inmediata para partir con las armas y bestias necesarias ${ }^{71}$. Aunque no servían con las armas, los concejos también tenían que seguir el mismo proceso de repartir, señalar y tener preparadas las gentes de oficios como carpinteros, hacheros, aserradores, pedreros o herreros necesarios en los reales ${ }^{72}$. Sin embargo, al contrario que con los combatientes, no hay ningún testimonio que indique lo que pueda considerarse como una inspección previa. Los llamamientos de la monarquía a las ciudades, villas y lugares para la provisión de tropas especificaban el lugar de reunión, el número con el que debían contribuir, el momento y forma de pago, ${ }^{73}$ así como las provisiones ${ }^{74}$ que tenían que llevar esas tropas.

Respecto a Paredes de Nava su principal aportación a la campaña contra Antequera en I4Io fue la de combatientes: ballesteros y lanceros, hasta ciento sesenta divididos en dos turnos y por un tiempo de dos meses. El primer turno lo integraron treinta ballesteros y sesenta lanceros ${ }^{75}$ y el segundo, sin que se especifique el número de ballesteros o lanceros, setenta en total $7^{76}$, aunque nos inclinemos por veinticinco ballesteros y cuarenta y cinco lanceros. Los primeros noventa son los que escogió Diego Rodríguez Zapata y los setenta últimos el concejo de Paredes sería el encargado de hacerlo ${ }^{77}$. Ambos contingentes irían bajo el pendón de Paredes, como se puede deducir de un pago que el concejo manda hacer, al final

Historia. Instituciones. Documentos, 7 (1980), n. ${ }^{\circ}$ V, pp. 281-286, y por el mismo en Dıos, Salustiano de: Fuentes para el estudio del Consejo Real de Castilla, Salamanca, Diputación de Salamanca, 1986, n. ${ }^{\circ}$ V, pp. 21-27.

70. Por ejemplo, en Archivo Municipal de Écija, (AMÉ)., leg. IV, n. ${ }^{\circ}$ 22, publicado por Sanz Fuentes, María Josefa: op. cit., vol. III, n. ${ }^{\circ}$ 422, pp. 1461-1463, o en Archivo Municipal de Jerez de la Frontera (AMJF)., Actas Capitulares (1410 abril 12), fols. 66 duplicado-67r, publicado por GonzÁlez SÁnCHEZ, Santiago: Las aportaciones de Jerez de la Frontera a la campaña de Antequera. Colección documental de las Actas Capitulares, Sevilla, Publidisa, 2011, n. ${ }^{\circ}$ 44, pp. 80-82.

71. Aunque se refiere a la segunda mitad del siglo XIII y a la primera del XIV creemos perfectamente válidas para la época de este estudio las afirmaciones que hace al respecto GARCíA FITZ, Francisco: «La didáctica militar en la literatura castellana (segunda mitad del siglo XIII y primera del XIV)», Anuario de Estudios Medievales, 19 (1989), pp. 274-277, que señala la inexistencia de indicios de instrucción colectiva, de prácticas de movimientos tácticos de todo un conjunto de combatientes. Lo que sí que habría existido fue una instrucción militar individual, la del caballero, que comprendería actividades como: aprender a cabalgar, el manejo de armas ofensivas y defensivas, la práctica de la caza y lecturas y narraciones de hechos de armas y de cantares de gesta, además de poner en práctica consejos y costumbres para que se adaptasen a las condiciones de la guerra.

72. AMÉ., leg. IV, n. ${ }^{\circ}$ 153, publicado por SAnz Fuentes, María Josefa: op. cit., vol. III, n. ${ }^{\circ}$ 431, pp. 1480-1481. AMJF., Actas Capitulares (1410 marzo 18), fols. 41v-42r y 42r, publicados por GonZÁlez SÁNCHEZ, Santiago: Las aportaciones de Jerez..., n. ${ }^{\circ} 17$, pp. $48-49$ y n. ${ }^{\circ} 18$, p. 50 , respectivamente.

73. AMJF., Actas Capitulares (1410 abril 12), fols. 66 duplicado-67r, publicado por GonzÁLez SánCHEz, Santiago: Las aportaciones de Jerez..., n. ${ }^{\circ} 44$, pp. $80-82$.

74. AMJF., Actas Capitulares (1410 abril 16), fol. 72v, publicado por GonZÁLEZ SÁnCHEZ, Santiago: Las aportaciones de Jerez..., n. ${ }^{\circ}$ 54, pp. 91-92, y por ABELLÁN PÉREZ, Juan: Diplomatario del Reino de Granada..., n. ${ }^{\circ}$ 28, pp. 130-131.

75. AMPdN., CP., 238/12, carp. 11, f. 8v.

76. AMPdN., CP., 238/12, carp. 11, ff. 31v, 37r y 39 r.

77. AMPdN., CP., 238/12, carp. 11, f. 31v. 
de la campaña, al hijo de «Pero Bueno por el pendón que traxo que le mandaron dar los omnes bonos quinse mrs que traya de Antiquera fasta aquí el pendón $\gg^{78}$.

Esta ayuda de Paredes de Nava comportaba un reto de organización logística importante. En primer lugar el de escoger y encuadrar a los combatientes y, tan relevante como esto, el reparto, la recaudación y la distribución del dinero necesario para satisfacer los pagos, todo lo cual implicaba a un elevado número de personas.

El infante escogió para la primera tarea a Diego Rodríguez Zapata, un hombre de su casa que lo había servido durante la campaña de I407 y de total confianza ${ }^{79}$. La primera noticia que tenemos de Rodríguez Zapata ${ }^{80}$ en Paredes de Nava es del año I409, momento en que llegó a la citada población enviado por el regente castellano y señor de la villa para conocer cuántos moradores había en ella ${ }^{81}$, después consta su presencia a finales de octubre del mismo año, cuando hizo alardes y escogió a ciertos hombres para que sirviesen en la guerra contra los granadinos cuando se les llamase $^{82}$. Es probable que Rodríguez Zapata estuviese en Paredes para el fin ya expuesto en alguna ocasión más, pero la documentación disponible no lo aclara y cuando el concejo requirió su presencia «... porque estouiese aquí fasta que fuesen ydos los lançeros et vallesteros que él auía manferido» ${ }^{8}$. Lo que sí es cierto es que Diego Rodríguez Zapata también escogió a los peones de Saldaña y de su tierra destinados a combatir a los granadinos ${ }^{84}$.

Conocemos los nombres de la práctica totalidad de los combatientes y las aportaciones de cada uno de los barrios de Paredes, de acuerdo con dos documentos de carácter fiscal. Uno de los cuales se refiere a las «retenencias», retenciones que se les hicieron del pago del fumazgo y el otro a las que se les aplicaron por el pecho de $14 \mathrm{IO}^{85}$. De acuerdo con ello se ha elaborado el siguiente gráfico que representa el número de total de combatientes por cada barrio y dentro de ellos el número que tuvo retenciones en el fumazgo y en el pecho.

Como se observa en el siguiente diagrama, los barrios en los que se escogió más gente para combatir y, por consiguiente, a los que se les retuvieron más cantidades fueron los de Calleluenga, Gallegos y Mediano, treinta y cinco, veintisiete y veinte,

78. AMPdN., CP., 238/12, carp. 11, f. 6 v.

79. Se le encargó, junto con otros caballeros y escuderos hijosdalgo de la casa del infante don Fernando, «... llevar toda la pólvora, é de las carretas é bueyes que han de llevar, que son menester ochenta hombres, é que lleven mas cinco carretas vacías, porque si alguna se quebrare no se detenga la pólvora», desde Zahara (actual Zahara de la Sierra) a Setenil durante la campaña militar de 1407. Pérez de GuzMáN, Fernán: op. cit., p. 292. Casi en los mismos términos, aunque sin recoger el segundo apellido de nuestro personaje, GARCíA DE SANTA MARíA, Álvar: Crónica..., p. 145. CAÑAS GÁLVEZ, Francisco de Paula: «La Casa del Infante Fernando de Castilla: corte, poder y representación político-institucional en el ocaso del Medievo (1385-1408)», Boletín de la Real Academia de la Historia, CCXIII/ I (2016), p. 42.

8o. Es posible que fuese vecino de Urueña, como se deduce por una misiva del concejo de Paredes a su mujer. AMPdN., CP., 238/12, carp. 11, f. 25r.

81. AMPdN., CP., 238/11, carp. 10, f. $9 v$.

82. AMPdN., CP., 238/11, carp. 10, f. 14V.

83. AMPdN., CP., 238/12, carp. 11, f. 25r.

84. AMPdN., CP., 238/12, carp. 11, f. 23 r.

85. Véase el Apéndice Documental, n. ${ }^{\circ} 1$ y n. ${ }^{\circ} 2$. 
respectivamente. Y los que aportaron menos combatientes fueron los de Renedo con trece y la Fuente con once ${ }^{86}$.

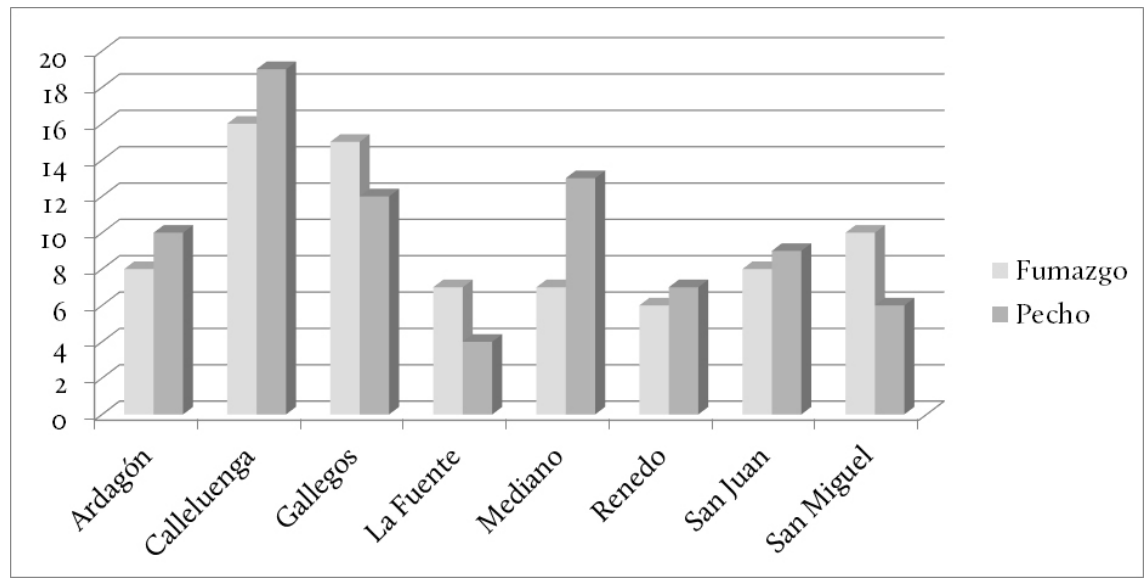

Estas exenciones temporales del pago de impuestos a un número tan elevado de vecinos de Paredes, los ciento sesenta que acompañaron al infante don Fernando, tuvieron un impacto fiscal sobre las debilitadas arcas municipales, provocando una disminución en el número de hogares en I4IO, siendo inferior a I409 y a I4II ${ }^{87}$.

Por otro lado, la reacción de los habitantes de Paredes de Nava ante la posibilidad de ser encuadrados en un ejército que tenía que combatir lejos de su tierra y contra los musulmanes no despertaría mucho entusiasmo entre la población, a pesar de las obligaciones vasalláticas que tenían respecto a su señor. En tal sentido conocemos varios casos de combatientes que se ausentaron, casi con toda certeza después de ser escogidos. Así se nos informa que García González Berruguete, procurador del concejo de Paredes, a instancia de éste escogió como lanceros «... a Juan de Villacorta et Alfón Gonçáles Berruguete mi fijo para que fuesen a la guerra la primera ves en logar de Juan Chamorro et Juan de Monçón por quanto estos fueron nombrados para yr allá et non podieron ser auidos» ${ }^{88}$. Entre los primeros combatientes, se debieron de marchar de la villa de Paredes de Nava el hijo de Bartolomé Pajares, Juan de San Felices y Juan Díez. Del primero ignoramos las circunstancias de su ausencia, de cada uno de los otros dos conocemos «... que non era en la tierra», así como que el hijo de Bartolomé Pajares y Juan de San Felices eran lanceros y que todos ellos fueron sustituidos ${ }^{89}$. Los lanceros

86. Esencialmente coincidiría con el número de hogares por barrios según los repartimientos de los fumazgos que conocemos por Martín CEA, Juan Carlos: op. cit., p. 35.

87. Ibidem, pp. 36 y 52. Véase también Fuente Pérez, María Jesús: «Fuegos fiscales...», p. 93.

88. AMPdN., CP., 238/12, carp. 11, f. gr.

89. AMPdN., CP., 238/12, carp. 11, f. 9 r. 
Juan Díez y Juan de San Felices fueron penalizados por el concejo y obligados a devolverle cada uno de ellos doscientos cincuenta maravedíes ${ }^{\circ 0}$. También se dio la circunstancia de que una pendencia, no sabemos de qué tipo, desaconsejó la inclusión de algún combatiente, como ocurrió con Alfón Tonquetano, al que el concejo mandó quitar los doscientos veinticinco maravedíes que «... le auía mandado pagar porque non fuese al real por quanto él et otro fijo de Sanguillo estodieron en contienda ${ }^{9 \mathrm{I}}$.

Abundando en esa aversión a empuñar las armas de parte de la población joven y masculina de Paredes de Nava, también encontramos lo que la documentación denomina «carta de composición», por la que alguien escogido para ir a la guerra contrataba a otro para que ocupase su lugar. Acuerdos de este tipo fueron los que hicieron «Gómes pregonero con Garçía Gonçáles de yr a la guerra en logar de Pero Todidor» ${ }^{92}$ y Alfón Gutiérrez con el citado García González Berruguete para ir en lugar de Juan Fernández de San Felices ${ }^{93}$. Es fácil suponer una diferenciación, al menos económica, entre el combatiente elegido en el alarde y el que acabaría ocupando su puesto ${ }^{94}$.

\subsection{EL REPARTO Y LA RECAUDACIÓN DE DINERO}

El reparto y la recaudación del dinero necesario para pagar los sueldos de los ballesteros y lanceros que la villa de Paredes de Nava envió a la campaña militar de I4Io se hizo en distintos momentos y a lo largo de varios meses de ese mismo año. Se recurrió a la imposición de tributos extraordinarios como un fumazgo ${ }^{95}$ y un pecho por los ocho barrios de la población, un fumazgo por cada cabeza de animal, así como a la parte correspondiente de las trece monedas que el rey había mandado recaudar. También se acude a un préstamo, al pago del pecho de unas heredades, a la venta de la carne y del cuero de unos toros que se habían comprado

90. AMPdN., CP., 238/12, carp. 11, f. 3r.

91. AMPdN., CP., 238/12, carp. 11, f. 31v.

92. AMPdN., CP., 238/12, carp. 11, f. 37r.

93. AMPdN., CP., 238/12, carp. 11, f. 37V.

94. Ladero Quesada, Miguel Ángel: «Baja Edad Media», Historia Militar de España, Dirigida por Hugo O’ DonNELL, Edad Media, Tomo II, Miguel Ángel Ladero Quesada (Coordinador), Madrid, Ministerio de Defensa-Laberinto, 2010, p. 249.

95. Tal como tomamos de Fuente Pérez, María Jesús: «Sobre pechos y pecheros de un concejo medieval. Paredes de Nava», Espacio, Tiempo y Forma, Serie III, Historia Medieval, 5 (1992), p. 48, el término fumazgo tendría dos acepciones. La primera es que era el impuesto que se pagaba al señor por tener un hogar o por encender el fuego en él; la segunda, más compleja, es la de unidad de tributación. Por lo que aquí respecta, y al menos en el caso en que se impone con ese nombre a la posesión de una bestia mayor o menor, todo parece indicar que estaría más relacionado con la segunda, y referida a diferentes derechos señoriales. Las cifras medias que cada contribuyente paredeño pagó de fumazgo no son muy importantes, porque la mayor parte de ellos no contaba con bienes encabezados en una cantidad elevada. Solo cuatro vecinos, de una lista de veintiocho que habían combatido a los granadinos en 1410, estaban por encima de 10 maravedíes, eran: Juan Nabo con 12 mrs. y medio, Juan García de Cuenca con 17 mrs. y 6 dineros, Juan de Fontecha con 16 mrs y dos dineros y Pero Quadrado con 14 mrs y 5 dineros. Véanse al respecto AMPdN., CP., 238/12, carp. 11, ff. $32 r-v$, del Apéndice Documental, n. ${ }^{\circ} 2$. 
para unos festejos, a las mesas de los carniceros y a las rentas de la carnicería y de la monedilla. No obstante lo anterior, parece que en algún momento se recurrió a la alcabala para hacer frente a determinados gastos ${ }^{96}, \mathrm{y}$ además los habitantes de Paredes tuvieron que soportar el cobro de la Cruzada, una forma de apoyo ideológico y económico de la Iglesia a la empresa guerrera ${ }^{97}$, durante dos días ${ }^{98}$.

Desde un punto de vista cuantitativo y porcentual el fumazgo (n. ${ }^{\circ}$ I) que se recogió en los barrios de San Juan, Calleluenga, Ardagón y Gallegos, 8 I70 mrs. ${ }^{99}$ representa el 4,68 por ciento; el fumazgo $\left(n .^{\circ} 2\right)$ recogido para enviar a los últimos ballesteros y lanceros en los barrios de Mediano, San Miguel, La Fuente y Renedo, 7514 mrs. $^{\text {Ioo }}$ supone el 4,28 por ciento; el fumazgo (n. ${ }^{\circ} 3$ ) que se impuso por cada cabeza de animal, diferenciando entre bestias mayores y menores, se elevó a 5 23I mrs. ${ }^{\text {Ior }}$ un 2,98 por ciento; un pecho en los ocho barrios a razón de cuatro maravedíes y medio se distribuyó de forma equitativa, a razón de 7000 maravedíes por barrio y aportó la cantidad de 56000 mrs. ${ }^{102}$ un 31,92 por ciento; el préstamo del bachiller Ferrand García de 12 ooo mrs. ${ }^{103}$ un 6,84 por ciento; el pecho de unas heredades de Juan García de Paredes por importe de I 000 mrs. ${ }^{\text {I04 }}$ un 0,57 por ciento; lo derivado de las mesas de los carniceros, venta de carne y cuero de los toros, renta de la carnicería y de la monedilla, etc., $8434 \mathrm{mrs}^{\mathrm{I}}{ }^{105} \mathrm{un}$ 4,8 o por ciento, y la cantidad y porcentaje más elevado correspondió a las trece monedas del rey, que procuraron 77056 mrs. ${ }^{106}$ un 43 por ciento. Así pues, el total recaudado se elevó a 175405 maravedíes $^{\mathrm{I07}}$.

96. AMPdN., CP., 238/12, carp. 11, f. 38 r.

97. GoÑI GAZTAMBIDE, José: Historia de la bula de cruzada en España, Vitoria, Victoriensia: Publicaciones del Seminario de Vitoria, 1958. Una definición sobre este ingreso, su cronología, evolución y cuantía puede verse en LADERO QUESADA, Miguel Ángel: La Hacienda Real de Castilla en el siglo XV, La Laguna, Universidad de La Laguna, 1973, pp. 227-233. NIETO SORIA, José Manuel: op. cit., pp. 322-323, destaca que la idea de cruzada estaba en decadencia desde un punto de vista ideológico, no así desde el financiero.

98. Sabemos que estuvieron en la villa dos días, sábado y domingo, y que fueron doce personas, a las que el concejo dio de comer y en las que se gastó 112 mrs. y 21 dineros. AMPdN., CP., 238/9, carp. 11 , ff. 23r-v.

99. AMPdN., CP., 238/12, carp. 11, f. 2v.

100. AMPdN., CP., 238/12, carp. 11, f. 21v.

101. AMPdN., CP., 238/12, carp. 11, f. 21 r.

102. AMPdN., CP., 238/12, carp. 11 , f. 21 r.

103. AMPdN., CP., 238/12, carp. 11, f. 8v.

104. AMPdN., CP., 238/12, carp. 11, f. 3 r.

105. AMPdN., CP., 238/12, carp. 11, f. 21v.

106. AMPdN., CP., 238/12, carp. 11, f. 2v. Fuente PÉREZ, María Jesús: «Las cargas reales de un concejo de señorío. La villa de Paredes de Nava en la Baja Edad Media», Historia. Instituciones. Documentos, 27 (2000), p. 61, destaca la capacidad del señor para disponer de esos derechos reales. Un ejemplo reconociendo esto mismo en AMPdN., CP., 238/13, carp. 12, f. gr. «ltem una carta de pago quel conçejo dio a Diego Alfón Maço de conosçimiento cónmo auía tomado de las monedas e pedido del rrey para el sueldo de los vallesteros que enbiamos al rreal (de) Antiquera la postremera ves XXVIII mil CC mrs». Véanse también las consideraciones que hace al respecto ORTEGO RıCO, Pablo: «Guerra y paz como fundamentos legitimadores de la exacción fiscal: siglos XIII-XV», A. ARRAnz GuZmáN, M. P. RÁbADe ObRADó \& Ó. Villarroel GonzÁlez, (coords.), Guerra y paz en la Edad Media, Madrid, Silex, 2013, pp. 67-107.

107. Por poner un ejemplo cercano, aunque desconocemos su procedencia, el concejo de Villalón de Campos tenía que recaudar antes de finales de 1409 la cantidad de $85500 \mathrm{mrs}$. a los que hay que añadir los impuestos que las Cortes votaron, como tomamos de Martínez Sopena, Pascual: op. cit., p. 485. 


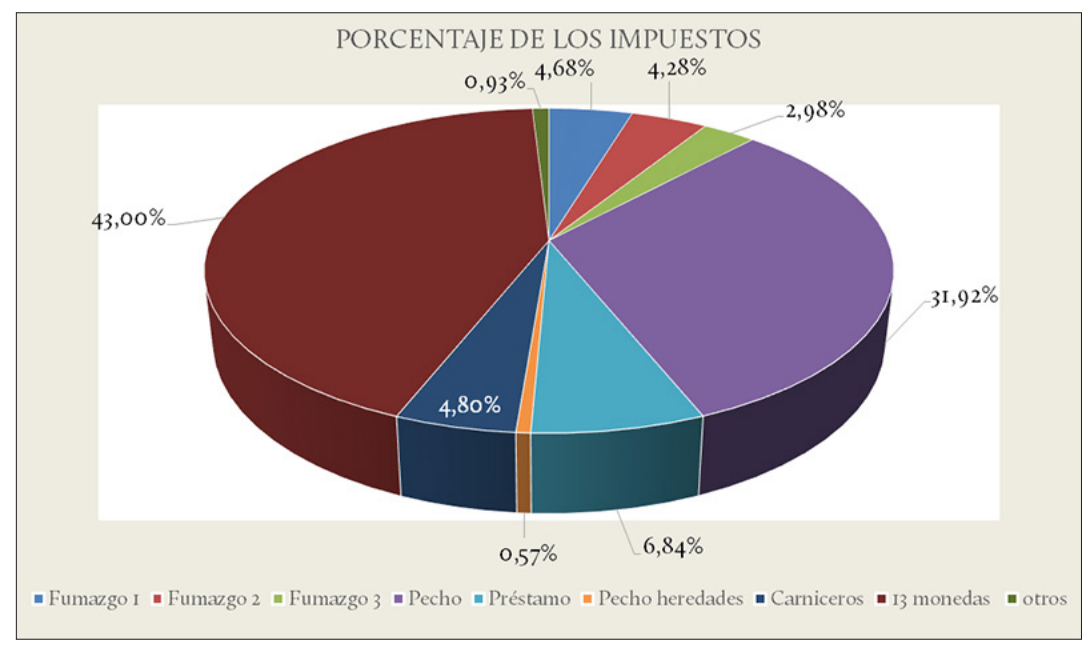

Si tenemos en cuenta los sueldos de las tropas, a razón de 8 maravedíes diarios el ballestero y 6 maravedíes diarios el lancero, ascienden a 480 maravedíes para los primeros y para los lanceros a 360 maravedíes, por los dos meses de servicio, es decir, una diferencia de 120 maravedíes. El sueldo diario de las tropas de Paredes era similar al de las procedentes de otras poblaciones del reino ${ }^{\text {I08 }}$ y se ajustaba a lo dispuesto por el monarca en $\mathrm{I}_{4} \mathrm{IO}^{\mathrm{IO} 9}$. Aplicando estas cantidades nos sale que los treinta ballesteros y los sesenta lanceros primeros supusieron un gasto de I4 400 y de 2I 600 maravedíes, respectivamente, en total 36 ooo maravedíes. Cantidad a la que hay que añadir 200 maravedíes por persona para los gastos de desplazamiento, es decir, I8 ooo mrs. En total, estos primeros combatientes le costaron al concejo de Paredes de Nava 54000 maravedíes.

El sueldo diario de las tropas enviadas la segunda y última vez era idéntico al de las primeras. Sin embargo, nos encontramos con el problema de que la documentación manejada no especifica con claridad el número de ballesteros y de lanceros que fueron a la guerra, solo un testimonio recoge un pago a treinta y cuatro lanceros $^{\text {IIO }}$, lo que no volvemos a ver refrendado por ninguna otra afirmación y tampoco se pone en relación con el número de ballesteros, en total setenta combatientes. Sin embargo, y teniendo en cuenta un documento donde se recoge

108. Véase González Sánchez, Santiago: Los recursos militares..., pp. 64-65. En el caso de los combatientes de Villalón de Campos, los cincuenta y ocho que fueron regresaron y recibieron $23880 \mathrm{mrs}$, por un mes, como tomamos de MARTínez SopenA, Pascual: op. cit., p. 488. De acuerdo con las cifras que hemos aportado de 8 mrs. diarios el ballestero y 6 mrs. el lancero, el sueldo de los veinticinco ballesteros importó 6 ooo mrs. y el de los lanceros 5940 mrs. Cifras a las que habría que añadir los 200 mrs. a cada uno para el desplazamiento. Lo que arroja la cifra de 23540 y un desfase de $340 \mathrm{mrs}$. que ignoramos a qué puede deberse.

109. Orden por la que el monarca mandaba dar cada día ocho maravedíes a los ballesteros y seis a los lanceros. AMJF., Actas Capitulares (1410 marzo 24), f. 5or, regesto en GonZÁLez SánCHEZ, Santiago: Las aportaciones de Jerez..., n. ${ }^{\circ}$ 27, p. 6o. También está recogido en la publicación anterior.

110. AMPdN., CP., 238/12, carp. 11, f. gr. 
la cantidad total del pago de un mes a estos segundos combatientes, I4 Ioo maravedíes, las cifras debieron de ser veinticinco ballesteros y cuarenta y cinco lanceros ${ }^{\text {III }}$. Cifras que desde el punto de vista porcentual casi coinciden, varían poco, con los números de los combatientes del primer envío, que representaban un tercio del total para los ballesteros y que en este segundo caso serían un poco más elevadas, un treinta y cinco por ciento, mientras que los lanceros eran el sesenta y cuatro por ciento. Así pues, y teniendo en cuenta esas cifras, el sueldo de los veinticinco ballesteros se elevó a I2 000 maravedíes -a razón de 480 mrs.- y el de los cuarenta y cinco lanceros a I6 200 maravedíes -a razón de 360 mrs.-, en total 28 200. Y como en el caso anterior a esta última cantidad hay que sumarle los 200 maravedíes por combatiente para ayuda de desplazamiento, I4 ooo maravedíes. Por lo que el desembolso de Paredes en estos setenta combatientes habría sido de 42200 maravedíes. Cantidad a la que hay que añadir el sueldo de otro mes que don Fernando ordenó enviar «... con los setenta vallesteros et lançeros que fueron la postremera ves con un (sic) buen omne... demás de otros dos meses que les fueron pagados aquí en la dicha villa por mandado del dicho sennor infant». Sueldo que se elevaría hasta los I4 Ioo maravedíes.

Por lo tanto, los cinco meses de sueldo que se pagaron a las tropas, dos a los primeros combatientes importaron 36 ooo maravedíes y los tres a los setenta últimos 42300 maravedíes. En total 78300 maravedíes por este concepto. Mientras que los gastos que el concejo de Paredes pagó por el desplazamiento se elevaron a 32000 maravedíes. Porcentualmente los 78300 maravedíes de sueldo representaban el 70,98 por ciento de los gastos y los 32000 maravedíes por desplazamiento suponían el 29,or por ciento.

Así pues, el gasto total del concejo en los sueldos y desplazamientos de los ballesteros y lanceros enviados a la campaña de I4Io se elevó hasta los IIO 300 maravedíes. La cuestión que se plantea es ¿en qué se emplearon los 65 I05 maravedíes restantes del total recaudado de 175 405? Parece fuera de toda duda de que parte de ese dinero, que podemos considerar sobrante y del que tampoco se dispuso en el momento preciso para hacer frente a los gastos, se debió de utilizar para pagar ciertos desembolsos como serían acompañar a los combatientes durante unas jornadas ${ }^{\mathrm{II} 2}$, o hasta el real sobre Antequera, como ocurrió con el bachiller Ferrand Martínez ${ }^{\mathrm{II}}$, o en previsión de un alargamiento de la campaña ${ }^{\mathrm{II} 4}$. En cualquier caso,

111. A la misma conclusión llega Martín CEA, Juan Carlos: op. cit., pp. 51-52, aunque no señala el documento del que procede su afirmación.

112. El caso de Toribio Fernández Valiente, que fue hasta Medina del Campo con los setenta ballesteros y lanceros últimos. AMPdN., CP., 238/12, carp. 11, f. 2v.

113. AMPdN., CP., 238/12, carp. 11, f. 27 r.

114. «Item que enbió el dicho sennor infant mandar por otra su alualá al conçejo que enbiasen a Antiquera con los setenta vallesteros et lançeros que fueron la postremera ves con un (sic) buen omne de recabdo sueldo de un mes para los dichos setenta vallesteros et lançeros demás de otros dos meses que les fueron pagados aquí en la dicha villa por mandado del dicho sennor infant...». AMPdN., CP., 238/12, carp. 11, f. gr. 
la diferencia es tan elevada y la carencia de apuntes contables total, que ignoramos qué se hizo con certeza con toda esa moneda.

Aunque el encargado de recaudar el dinero necesario para satisfacer los sueldos fuera el concejo de Paredes ${ }^{15}$ y en alguna ocasión algún regidor como García González Serrano o el procurador Juan Fernández Bueno realice algún pago ${ }^{\mathrm{II}}$, se intentará centralizar en personas del entorno de don Fernando como Ferrand Martínez, su recaudador del sueldo, en el tesorero Juan García o en su defecto en su «hacedor» Juan García de Paredes ${ }^{117}$, en Alfonso García, vecino de Sahagún y arrendador del infante en Saldaña y su tierra ${ }^{\text {II8 }}$, en Alfonso García de Castro recaudador del infante ${ }^{\mathrm{II}}$, incluso en Diego Rodríguez Zapata ${ }^{120}$. Y al mismo tiempo que lo anterior se intenta reunir el dinero en ciertos lugares, como Medina del Campo, donde el infante mandó llevar I8 ooo maravedíes «... para pagar el sueldo a los lanceros y ballesteros que estaban en la guerra» ${ }^{\mathrm{I} 2 \mathrm{I}}$, o transportarlo hasta Antequera, como ocurrió cuando el concejo envió a los setenta ballesteros y lanceros últimos:

... el dicho sennor infant mandó leuar sueldo de vn mes en pos ellos e quelos leuase vn omne bueno el qual fue el dicho Alfón Gonçáles et leuó los dichos mrs que montaron en el dicho mes et los dio a Diego Alfón Maço por mandado del dicho sennor infant et traxo su carta de pago ${ }^{122}$.

A pesar de las prevenciones que se tomaron también ocurrió que algún servidor deshonesto se resistió a entregar ciertas cantidades del dinero que había recibido. Nos referimos a Alfonso García de Castro, recaudador del infante don Fernando, que fue requerido en varias ocasiones en Sahagún, localidad donde estaba avecindado, «... sobre los veynte et quatro mill et dosientos mrs que auía de dar a los lançeros e vallesteros desta villa et otrosy que los leuase a su costa do quier quel dicho sennor infant estouiese $»^{\mathrm{I23}}$. La negativa de este García de Castro a entregar a los encargados del concejo de Paredes la mitad de los 24200 maravedíes tras concederle un plazo de veinte días ${ }^{124}$, obligó al infante a ordenar que «... sy Alfón Garçía de Castro non diese luego los veynte e quatro mill e dosientos

115. Sobre el papel de los concejos en la financiación de la guerra, en concreto, en el proceso de recaudación, es interesante, aunque sea muy anterior a nuestra época de estudio, el apartado correspondiente de la obra de ARIAS GUILLÉN, Fernando: Guerra y fortalecimiento del poder regio en Castilla. El reinado de Alfonso XI (1312-1350), Madrid, CSIC-Ministerio de Defensa, 2012, pp. 269-320, en especial.

116. AMPdN., CP., 238/12, carp. 11, f. gr. Los nombres completos de estos oficiales del concejo de Paredes de Nava los tomamos de MARTín CEA, Juan Carlos: op. cit., p. 277.

117. AMPdN., CP., 238/12, carp. 11, f. gr.

118. AMPdN., CP., 238/12, carp. 11, f. 22v.

119. AMPdN., CP., 238/12, carp. 11, ff. $23 v$ y 25 r.

120. AMPdN., CP., 238/12, carp. 11, f. 22v.

121. AMPdN., CP., 238/12, carp. 11, ff. 8v y gr. Conocemos que el concejo de Paredes de Nava envió a un vecino «... porque fue leuar a Villalón una carta del conçejo para el conçejo de Villalón a saber sy ello leuauan los mrs quel sennor infant mandó tomar de las monedas a Medina». AMPdN., CP., 238/12, carp. 11, f. $26 \mathrm{v}$.

122. AMPdN., CP., 238/12, carp. 11, f. 29 v.

123. AMPdN., CP., 238/12, carp. 11, f. 25r. También en ff. 26v, 30r y 31 r.

124. AMPdN., CP., 238/12, carp. 11, f. 26v. 
mrs quel prendiesen el cuerpo para los alcalles de la villa de Sant Fagund et le enbiasen bien preso a su costa do quier quel dicho sennor infant estouiese ${ }^{125}$. La documentación consultada no vuelve a mencionar el asunto, por lo que es posible que se resolviese de forma favorable para los intereses del concejo de Paredes.

El caso citado sería indicativo de cómo se distribuyó el dinero entre los combatientes paredeños. En tal sentido, nos han llegado pagos muy diversos en número de combatientes y en cantidad de dinero. Ejemplos de ello y de los varios que se podrían presentar son los siguientes.

Item que pagó el dicho Garçía Gonçáles en los nouenta vallesteros et lançeros primeros que fueron a la guerra primeramente demás de otros díes et nueue vallesteros que pagó Juan Ferrándes Bueno procurador et demás de otros dos vallesteros que pagó Diego Rrodrígues Çapata et para complimiento de los treynta vallesteros pagó Garçía Gonçáles los nueue vallesteros a rrasón de ocho mrs cada vallestero cada día en dos meses que monta cada uno quatroçientos et ochenta mrs et más quel conçejo les dio et mandó dar a cada uno de ayuda para partir de aquí de más del dicho sueldo a cada uno dosientos mrs asy que pagué a cada uno seiçientos et ochenta mrs que montó a los dichos nueue vallesteros por los dichos dos meses seys mill e çiento e veynte mrs.

Item que pagué más yo el dicho Garçía Gonçáles a çinco lançeros que fueron a la dicha guerra primeramente demás de los çinquanta et tres lançeros que pagó Juan Ferrándes mi compannero e demás de otros dos lançeros que pagó Diego Rrodrígues Capata que son a complimiento de sesenta lançeros que fueron a la dicha guerra a los quales dichos çinco lançeros pagué sueldo de dos meses a rrasón de seys mrs cada día por dos meses que montó a cada uno tresientos et setenta mrs et más que les dy a cada uno dosientos mrs que les mandó dar el conçejo para ayuda de partyr de aquí demás del dicho sueldo que montó en todos estos dichos lançeros dos mill et ochoçientos mrs. ${ }^{126}$

Item pagué yo más el dicho Garçía Gonçáles a dies e nueue vallesteros que fueron a la dicha guerra la postrimera yda demás de otros seys que pagó Juan Ferrándes mi compannero que les dy de sueldo a ocho mrs cada día a cada uno de dos meses, que montó a cada uno quatroçientos et ochenta mrs más que les mandó dar el conçejo a cada uno dosientos mrs para ayuda de partyr de aquí, que montó en todo arrasón de seysçientos et [çinquenta tachado] XX mrs a cada uno, dose mill e noueçientos e ueynte mrs.

Item que pagué más a treynta et quatro lançeros que fueron la segund ves a la dicha guerra a rrasón de a seys mrs cada día a cada uno sueldo de dos meses, que montó a cada uno tresientos e sesenta mrs más, quel conçejo mandó dar a cada uno de ayuda para partir de aquí dosientos mrs a cada uno, que montó a cada uno quinientos et sesenta mrs, asy que montó en los dichos treynta e quatro lançeros dies e nueue mill e quarenta mrs. ${ }^{127}$

De cualquier manera, todo indicaría que cuando los ballesteros y lanceros salían de Paredes de Nava iban al corriente de pago.

Item cartas de pago que dieron los lançeros e vallesteros primeros que fueron a la guerra la primera ves de cónmo era pagados de sueldo de dos meses quel infant les mandó pagar que son quatro cartas.

125. AMPdN., CP., 238/12, carp. 11, f. 27r.

126. Ambos casos en AMPdN., CP., 238/12, carp. 11, f. 8v.

127. Los dos ejemplos en AMPdN., CP., 238/12, carp. 11, f. gr. 
Item cartas (sic) de pago que dieron los lançeros e vallesteros postrymeros que fueron a la guerra del sueldo de dos meses ${ }^{128}$.

Sin embargo, testimonios de I4II demuestran que en fecha 27 de abril de ese año el concejo de Paredes debía a los ballesteros y lanceros de la villa cierta cantidad, que no se especifica y ellos al concejo de los pechos ${ }^{129}$. Y el viernes 8 de mayo del mismo año el concejo mandó dar a un número indeterminado de ballesteros y lanceros la cantidad de ciento cinquenta y cuatro maravedíes que les adeudaba ${ }^{130}$. A esta situación se había llegado porque el concejo de Paredes de Nava, asegurándose la inversión que hacía en estos combatientes, les había retenido ciertas cantidades en concepto de fumazgo, por ejemplo a los ballesteros y lanceros que fueron a la guerra la primera vez, diez maravedíes por cabeza, como conocemos por treinta y nueve casos de los barrios de Calleluenga, Ardagón y Gallegos ${ }^{13 \mathrm{I}} \mathrm{y}$ por treinta y dos de los barrios de Mediano, San Miguel, la Fuente y Renedo ${ }^{132}$, en total setecientos diez maravedíes. También retuvo el pecho, a razón de cuatro maravedíes y medio por cabeza, a los que estaban en el real, de los que nos han llegado ochenta nombres de combatientes de los barrios de San Juan, la Fuente, Renedo, Mediano, San Miguel, Calleluenga, Ardagón y Gallegos, que se elevaron a 2009 maravedíes y cuatro dineros y medio ${ }^{\mathrm{I} 33}$. La devolución de la cantidad que le correspondía a cada uno estaría detrás de los «debates» que mantenían los ballesteros y lanceros que fueron a la guerra, de una sentencia y compromiso dada por Diego Alfón entre el concejo y los ballesteros y lanceros primeros y últimos, y de una carta de pago que dieron ambos de que «eran pagados de todo segund lo mandó Diego Alfón por sentençia» ${ }^{134}$.

\subsection{LA MILICIA CONCEJIL PAREDEÑA}

Numerosas ciudades y villas de Castilla contribuyeron con tropas de a caballo y de a pie en las campañas contra los granadinos durante la minoría de Juan II, especialmente las de Andalucía, además de Sevilla y los lugares de su Tierra: Utrera, Alcalá de Guadaíra, Lebrija, Alcalá del Río, Salteras y Castilleja del Campo, y Córdoba, valga citar a Jaén, Úbeda, Baeza, Jerez, Arcos, Olvera, Espera, Bornos, Morón, Alcalá de los Gazules, Écija, Carmona, Villanueva del Camino, etc. Fuera de Andalucía tenemos constancia de que en alguna de estas campañas estuvieron

128. AMPdN., CP., 238/12, carp. 11, f. 37r.

129. AMPdN., CP., 238/13, carp. 12, f. 25 r.

130. AMPdN., CP., 238/13, carp. 12, f. 25v. Ese día 8 de mayo Juan García, yerno de Juan de Guayo, percibió treinta y seis maravedíes. Más ejemplos en los ff. $26 r$ y v.

131. AMPdN., CP., 238/12, carp. 11, f. 10r.

132. AMPdN., CP., 238/12, carp. 11, ff. 34r-v.

133. AMPdN., CP., 238/12, carp. 11, ff. 31v-34r.

134. AMPdN., CP., 238/13, carp. 12, f. 46 r. 
tropas procedentes de Sahagún, Burgos, Cuenca, Murcia y su reino, la villa de Alcántara, Tordesillas, Palencia, Villalón de Campos, Guadalajara, Piedrahíta, Alba de Tormes, Plasencia, Galicia, o el caso que nos ocupa de Paredes de Nava. Los concejos organizaban sus milicias a partir de sus competencias militares y de la obligación que tenían los pecheros de prestar un servicio militar ${ }^{135}$.

Al ser nuestra fuente, las Cuentas de Propios, esencialmente de carácter fiscal, no nos informa de los momentos en que estas tropas partieron de Paredes de Nava, lo máximo que podemos conocer es que «... fueron en seruiçio del rey y del infant a la guerra de los moros», que los procuradores tomaron testimonio del día que partieron los ballesteros y lanceros de la villa para la guerra ${ }^{136}$, o que los alcaldes y regidores de Paredes de Nava se reunieron con los ballesteros y lanceros elegidos el «Lunes de las ochauas de Pascua» ${ }^{137}$, es decir, antes de partir. Esta última información puede ser interesante habida cuenta de que el lunes de las ochavas de Pascua -debe referirse a la Resurrección- sería el 3i de marzo de i4Io, pues la Pascua había sido el día 23 de ese mes. En ese sentido conocemos que el concejo pagó a cuatro individuos que fueron a la guerra, en marzo de I4Io, la cantidad de 2000 maravedíes $^{138} \cdot\langle$ Quiere eso decir que formaban parte del primer contingente que se envió? Si es así, pues no lo sabemos con certeza, llama la atención la ausencia de referencias a un posible encuadramiento y acompañamiento de algún hombre bueno del concejo durante los primeros días, como ocurre en otro caso ${ }^{\mathrm{I} 39}$. Por lo que los citados testimonios avalarían la hipótesis de que las tropas paredeñas estuvieron en la campaña militar de I4Io desde su comienzo.

Sobre el itinerario seguido por estas tropas hasta el real de Antequera podemos hacernos una ligera idea a partir de la costa que hizo el bachiller Ferrand Martínez. El concejo de Paredes de Nava envió al citado bachiller con los noventa ballesteros y lanceros primeros, con el propósito de que informara al infante-regente de algunas cuestiones que afectaban al concejo de Paredes y de la negativa de Alfonso García

135. Sobre las milicias concejiles existe una amplia bibliografía baste señalar: TENORIO CERERO, Nicolás: op. cit., pp. 1-44; Groizard y Coronado, Carlos: «Las milicias locales en la Edad Media. La compañía de ballesteros de Calahorra», Boletín de la Real Academia de la Historia, LV (1909), pp. 359-362; SánCHEZ SAUS, Rafael: op. cit., pp. 393-418; AgUdelo Herrero, Joaquín \& Jiménez Aguilar, María Dolores: «Las milicias del concejo de Sevilla en el contexto del ejército medieval», La organización militar en los siglos XV y XVI. Actas de las II Jornadas Nacionales de Historia Militar, Málaga, Cátedra «General Castaños», 1993, pp. 243-248; GONZÁLEZ JIMÉNEZ, Manuel: «Las milicias concejiles andaluzas (siglos XIII-XV)», La organización militar en los siglos XV y XVI. Actas de las II Jornadas Nacionales de Historia Militar, Málaga, Cátedra «General Castaños», 1993, pp. 227-241; PARreño CASAdO, Manuel: «Las milicias de Sevilla», La organización militar en los siglos XV y XVI. Actas de las II Jornadas Nacionales de Historia Militar, Málaga, Cátedra «General Castaños», 1993, pp. 248252; CONTRERAS GaY, José: «La importancia histórica de las Milicias Concejiles en la guerra fronteriza y su influencia en la Edad Moderna», Estudios de Frontera. Alcalá la Real y el Arcipreste de Hita, (Francisco Toro Ceballos y José RodríGUez Molina, coords.), Jaén, Diputación Provincial de Jaén, 1996, pp. 121-134; Sánchez Saus, Rafael \& MARTín GutiérRez, Emilio, «Ordenanzas jerezanas del siglo xv sobre la milicia concejil y la frontera de Granada», Historia. Instituciones. Documentos, 28 (2001), pp. pp. 377-390, y BELLO LEÓN, Juan Manuel: «Las milicias concejiles castellanas a finales de la Edad Media. Un estado de la cuestión y algunos datos para contribuir a su estudio», Medievalismo, 19 (2009), pp. 287-331.

136. Esta última afirmación procede de AMPdN., CP., 238/12, carp. 11, f. $38 \mathrm{v}$.

137. AMPdN., CP., 238/13, carp. 12, f. 12 r.

138. AMPdN., CP., 238/12, carp. 11, f. $3 v$.

139. AMPdN., CP., 238/12, carp. 11, f. 8v. 
de Castro $^{\text {I4O }}$ de pagar a los combatientes paredeños, escogidos por Rodríguez Zapata, la cantidad de 24200 maravedíes. De acuerdo con los gastos de ese viaje algunas escalas de ese trayecto fueron Paredes de Nava, Santa María de Guadalupe, Córdoba y el real sobre Antequera, lugares donde Ferrand Martínez se detuvo a herrar a las cabalgaduras ${ }^{141}$. Por su parte, de los combatientes que fueron la segunda vez solo conocemos que una de sus paradas fue Medina del Campo, ya que el concejo de Paredes de Nava, en cumplimiento de la orden del infante don Fernando, dispuso que Toribio Fernández Valiente un «... buen omne que saliese con ellos dos jornadas porque los acaudillase ${ }^{142}$. La duración de ese viaje, que casi con toda seguridad se haría por el mismo trayecto que el que hicieron las tropas enviadas en primer lugar, podemos estimarla en aproximadamente diecinueve días o quizás en algo menos ${ }^{143}$.

Las preguntas que surgen de lo que acabamos de exponer son ¿si los dos meses por los que fueron encuadrados los ballesteros y lanceros que fueron a la guerra la primera vez contaron desde inicios del mes de abril de I4IO? ¿si los setenta combatientes que el concejo de Paredes reclutó para enviar la segunda vez eran el relevo de los anteriores? y ¿cómo fueron encuadrados? La primera pregunta es difícil de contestar, pero quizá la respuesta la encontremos en que el concejo de Paredes «... les dio et mandó dar a cada uno de ayuda para partir de aquí de más del dicho sueldo a cada uno dosientos mrs» ${ }^{\mathrm{I} 44}$, y en que el primer contingente de ballesteros y lanceros de Paredes llegaría ya asentado el real sobre Antequera, si tenemos en cuenta los gastos del viaje del bachiller Ferrand Martínez que acompañó a esas tropas $^{\mathrm{I} 45}$. Por ello, es posible pensar en que una cosa era el desplazamiento y otra la llegada al real y el inicio de las acciones de armas, momentos estos últimos a partir de los cuales comenzarían a contar los dos meses por los que iban a servir. Así pues, no sería descabellado suponer que las primeras tropas de Paredes de Nava llegaran al real sobre Antequera, en el mejor de los casos, en la última semana del mes de abril de I4Io o a comienzos del mes de mayo, por lo que deberían servir hasta finales del mes de junio o la totalidad de este.

La segunda cuestión planteada, la del relevo ${ }^{\mathrm{I} 4}$, es insoluble de momento, como en tantos otros casos, por el mutismo de las fuentes. No obstante, si se recurre a ejemplos de otras poblaciones, como Villalón de Campos ${ }^{147}$ o Jerez

140. Era recaudador del infante, como conocemos por AMPdN., CP., 238/12, carp. 11, f. 3or.

141. AMPdN., CP., 238/12, carp. 11, f. 27r.

142. AMPdN., CP., 238/12, carp. 11, f. 30v.

143. No basamos para ello en que cuando Alfonso González Serrano fue a Antequera, por mandado del concejo de Paredes para llevar el sueldo de un mes para los últimos combatientes paredeños, estuvo treinta y nueve días en «yda et venida». Hay que tener en cuenta que iba con una acémila y cargada de dinero. AMPdN., CP., 238/12, carp. 11, f. 29v.

144. AMPdN., CP., 238/12, carp. 11, f. 8v.

145. AMPdN., CP., 238/12, carp. 11, f. 27r.

146. Martín CeA, Juan Carlos: op. cit., p. 51, da por hecho de que los segundos combatientes eran el relevo de los primeros, pero no aporta ningún documento que demuestre tal afirmación.

147. Martínez Sopena, Pascual: op. cit., p. 486, se hace eco del descontento de los combatientes de Villalón, por la prolongación de la campaña, por las repercusiones que su ausencia tendría sobre sus tierras y bienes, por lo que 
de la Frontera ${ }^{\mathrm{I} 4^{8}}$, es muy probable que los setenta combatientes que Paredes de Nava envió la segunda vez relevasen a los ballesteros y lanceros primeros, entre otras razones por el elevado gasto que para la hacienda concejil hubiera supuesto mantener una tropa tan considerable, al margen del desgaste físico y psíquico para los combatientes.

El encuadramiento de las tropas paredeñas plantea serios problemas. El primero, y quizá más importante, es el de conocer quién les mandaría en el real, pues el señor de la villa era a la vez el jefe del ejército castellano y, además, su señorío se extendía por otras poblaciones que también aportaron tropas para la campaña de Antequera ${ }^{\mathrm{I} 49}$. Descartado el mando directo de don Fernando sobre esas tropas, entre otras razones por sus ocupaciones, nos quedarían los distintos miembros del estamento nobiliario. Creo que habría que descartar a los de la más alta nobleza, sin duda, por tener bajo su mando su propia mesnada señorial y en la que también se integraban las «lanzas» por las que el noble en cuestión percibía I 500 maravedíes anuales de la Hacienda real. Además, seguro que esa posible heterogeneidad hubiera provocado dudas sobre el trato, sobre la preeminencia de alguno de ellos sobre otro, etc. Así pues, y aunque no sea más que una mera hipótesis a la espera de confirmación, es posible suponer que las tropas de Paredes de Nava, al contrario que otras procedentes de concejos de realengo como Sevilla, dirigidas por su alcalde mayor por ejemplo, estuvieran al mando de alguno de los hombres de la Casa de don Fernando, ¿quizá de Diego Rodríguez Zapata que les había escogido, que contaba con la confianza del infante-corregente y que tenía experiencia en la lucha contra los granadinos, al menos y según nos consta desde I407?

Otra cuestión difícil de responder es si las tropas de Paredes quedaron agrupadas por decenas o por veintenas, como también ocurrió durante el cerco a Antequera, por el momento carecemos de datos para ofrecer una respuesta creíble.

\subsection{LAS DESERCIONES}

Sobre el comportamiento de los combatientes paredeños en el asedio a Antequera no sabemos nada ni por las crónicas reales ni por la documentación manejada, lo que sería indicio, por otra parte, de que su intervención no se diferenció de la de otras tropas de a pie, como la mayoría de las milicias concejiles ${ }^{150}$, tanto de

\footnotetext{
le pidieron al infante volver. Don Fernando habría ordenado a las villas de su señorío preparar el relevo y pagarles dos meses de sueldo, antes de partir y un tercero cuando llegaran al real. El 23 de septiembre de 1410 un nuevo contingente de ballesteros y lanceros partió de Villalón de Campos, ignorándose si esta tropa pasó de Medina del Campo, donde les habría llegado la nueva de la conquista de Antequera, como tomamos del citado autor.

148. GonZÁlez SÁnChez, Santiago: Las aportaciones de Jerez..., n. ${ }^{\circ} 67$, p. 107, n. ${ }^{\circ} 84$, pp. 120-121, n. ${ }^{\circ}$ 86, p. 122 y n. ${ }^{\circ}$ 90, pp. 126-127.

149. Como sería el caso de Peñafiel, según Pazos y Vela-Hidalgo, José de: Peñafiel. Memoria histórica, Salamanca, 1880, p. 169, que no proporciona ninguna referencia documental o de otro tipo.

150. Una puesta al día de la bibliografía sobre esta cuestión es la de BELLO LEón, Juan Manuel: op. cit., pp. $287-331$.
} 
realengo como de señorío ${ }^{151}$. La razón puede estar, en algún caso, en las misiones que a este tipo de tropas se les encomiendan y que, en ocasiones, tienen más que ver con labores de limpieza del real ${ }^{152}$, con el transporte de pertrechos ${ }^{153}$ o con la vigilancia ${ }^{154}$, que no son tan honrosas como los combates. En alguno de estos, como el que se dirigió contra la huerta de Málaga ${ }^{155}$ o el que se dio a Antequera, no se especifica la procedencia de estas tropas ${ }^{156}$.

No obstante lo anterior, y al igual que ocurrió con las tropas de otras poblaciones, algunos combatientes de Paredes abandonaron de forma repentina el real castellano, sin tener licencia para ello, convirtiéndose en prófugos. La documentación de Paredes de Nava menciona por una parte la existencia de once ${ }^{157}$ y por otra de diez $^{158}$ de estos desertores ${ }^{159}$, sin especificar si se encuadraban dentro del primer envío, del segundo o pertenecían a ambos. De ser en este último caso, y teniendo en cuenta el número total de combatientes que Paredes envió -ciento sesenta-, el número total de desertores osciló entre poco más del seis y casi el siete por ciento. Conocemos el nombre y apellidos de cinco de estos combatientes fugados, tres de los cuales eran ballesteros y los otros dos lanceros. A su regreso a la villa sin licencia el concejo les requirió lo que les habían dado para la partida, que eran doscientos maravedíes a cada uno, y lo que en la documentación aparecen como los derechos del sueldo que pagó a Diego Rodríguez Zapata por cada uno de ellos, que oscila entre los veintiocho maravedíes y dos dineros para los ballesteros y veinte maravedíes y cuatro dineros para los lanceros.

Item de Martín de la Vieja lançero quele dio el conçejo para la yda que partió de aquí para la guerra dosientos mrs. Item más de los derechos quel conçejo pagó por él a Diego Rodrígues Çapata que montó dosientos e veynte mrs e quatro dineros. Asy que monta todos los mrs que deue el dicho Martín de la Vieja (CCXX mrs y IIII d).

Item de Alfón yerno del sellero vallestero quele dio el conçejo para la partida de que fue a la guerra y dosientos mrs. Item más de los derechos quel conçejo pagó por él a Diego Rodrígues Çapata que son veynte e ocho mrs e dos dineros. Asy es todo lo que deue el dicho Alfón dosientos e veynte e ocho e dos dineros. (CCXXVIII mrs y II d) $)^{160}$.

151. Véase al respecto el apartado del mismo título del libro de González SÁnchez, Santiago: Los recursos militares..., pp. 144-151.

152. Pérez de Guzmán, Fernán: op. cit., p. 325; García de Santa María, Álvar: Crónica..., p. 337.

153. García de Santa María, Álvar: Crónica..., p. 299.

154. Sánchez Saus, Rafael \& Ocaña Erdozain, Alberto: «Armamento y fortificación. (Siglos XI a Xv)», Historia Militar de España, Dirigida por Hugo O' Donnell, Edad Media, Tomo II, Miguel Ángel LADERo QueSADA (Coordinador), Madrid, Ministerio de Defensa-Laberinto, 2010, p. 398.

155. García de Santa María, Álvar: Crónica..., pp. 326-327.

156. «... vallesteros e lançeros de los conçegiles». García de SANTA María, Álvar: Crónica..., p. 382. Tal como tomamos de Sánchez SAus, Rafael \& OCAÑA ERdozain, Alberto: op. cit., p. 391, «Los peones siempre fueron la masa imprescindible de los ejércitos medievales en operaciones de asedio y razzias, además de auxiliar de la caballería en batallas campales y «cabalgadas», pero no solían ser el elemento decisivo en las operaciones, además de que en su mayor parte solían carecer de preparación militar específica y de armamento eficaz más alla de ciertos límites».

157. «... honse omnes que se venieron del real syn mandado del infant». AMPdN., CP., 238/12, carp. 11, f. 1v.

158. «... los X omnes que se venieron de la guerra syn mandado del infant». AMPdN., CP., 238/12, carp. 11, f. $39 \mathrm{v}$.

159. Sobre el problema de las deserciones véase LADERo QUESADA, Miguel Ángel: «Baja Edad Media», pp. $285-286$.

160. AMPdN., CP., 238/12, carp. 11, f. 1 . 
¿Es posible que la mención de Diego Rodríguez Zapata en la documentación indique que estos cinco prófugos pertenecerían al primer grupo que se envió a combatir a los musulmanes? Quizá, ya que este personaje fue el que los eligió en I409.

No obstante lo anterior, es decir, la devolución de lo cobrado en concepto de desplazamiento y los derechos del sueldo, serían una parte mínima de la pena a la que se debieron de enfrentar. El mayor castigo, aunque no se especifica a quiénes se impuso, fue su prisión y el embargo y posterior venta de sus bienes.

Item que mandó en concejo a Tomas Valiente merino que prenda los cuerpos e enbargue los bienes de los $\mathrm{X}$ omnes que se venieron de la guerra sin mandado del infant. Item de otra carta de poder quel conçejo dio a los procuradores para vender los bienes destos $\mathrm{X}$ omnes por lo que deuían al conçejo e que el conçejo se obligaua de lo faser sano a los compradores ${ }^{161}$.

La condición, cantidad, calidad y valor de dichos bienes no nos ha llegado, al igual que el destino definitivo que tuvieron.

Tampoco se nos informa del momento en que esos combatientes de Paredes abandonaron el real castellano sobre Antequera y cuál pudo ser la razón. Quizá se aprovecharon de la circunstancia de «... que muchos de los concegiles de Córdova é Sevilla é Xerez y Carmona, é de todos los más lugares de Andalucía eran idos a sus casas ${ }^{162}$. Abandono que podría fecharse entre finales de junio y principios o mediados de julio de $\mathrm{I}_{4} \mathrm{IO}^{\mathrm{I} 63}$, cuando aún el cerco a Antequera no se había estrechado y todavía no se disponía de las máquinas de asedio y que, grosso modo, coincidiría, para los primeros combatientes paredeños, con los dos meses de sueldo que se les habían librado. Las razones habría que buscarlas en la indisciplina, en la falta de alimentos o en la importancia que pudieron tener para ellos -la mayoría de los ballesteros y lanceros de Paredes eran pecheros- la recogida del cereal que habían sembrado en sus tierras o que tenían que recolectar sus familias y que tenía lugar por esas fechas, la añoranza de sus familias, etc.

Por otro lado, la documentación consultada también es parca a la hora de cuantificar el posible número de combatientes heridos o muertos. Aunque no sea más que una hipótesis no deja de llamar la atención que cuando Juan Fernández Bueno, procurador del concejo el año I4Io, libre ciertas cantidades que se debían a los ballesteros y lanceros que habían luchado contra los granadinos, se mencione en varios casos el nombre del combatiente y se entregue el dinero a su mujer, hijo o yerno. Esto sería bastante evidente con Diego Corbo y con Juan Luengo.

161. AMPdN., CP., 238/12, carp. 11, f. 39v. Otra orden de embargar los bienes de Juan Fernández Desa y de Juan Díez porque no quisieron ir a la guerra en AMPdN., CP., 238/12, carp. 11, f. 37r.

162. Pérez de Guzmán, Fernán: op. cit., p. 327.

163. Creemos acertada esta cronología entre otras razones por el testimonio fechado el 18 de julio de 1410, procedente de Collantes de Terán Delorme, Francisco: op. cit., n. ${ }^{\circ} 84-$ I, p. 331 . Donde se recoge lo siguiente: «Fe del escribano del concejo Alfonso López, al mayordomo Suer Vázquez de Moscoso, haciéndole saber que el rey había mandado a esta ciudad que diese diez hombres de a caballo al corregidor, doctor Fortún Velázquez de Cuéllar, para que estuviesen con él, guardando los caminos para que la gente no abandonase el real sobre Antequera, y, en cumplimiento de ello, Sevilla mandó repartir estos diez hombres, para lo cual envió una carta a Utrera, Alcalá de Guadaira y Lebrija y otra a Alcalá del Río, Salteras y Castilleja (del Campo), para que enviasen dichos hombres al corregidor». 
Martes XIX días del mes de mayo este día dy a la muger de Diego Corbo çiento et treyngta et ocho mrs et nueue dineros. Item a la muger de Juan Luengo çiento et çinquenta mrs et dos cornados por alualá de Alfón Ferrándes escriuanno de los mrs que el conçejo les mandaron dar a los lançeros e ballesteros asy montan en este alualá çiento e ochenta, IX mrs II dineros. (IX mrs y II d) ${ }^{164}$.

En otros casos es más difícil probar que la entrega de dinero a otra persona que no era el que se había enfrentado a los granadinos se debería a una ausencia temporal, a una enfermedad o lesión o a su muerte en combate, además de posibles divergencias, omisiones de nombres o errores de transcripción de los combatientes.

\subsection{LAS NOTICIAS DE LA GUERRA Y SU ALCANCE EN PAREDES DE NAVA ${ }^{165}$}

La memoria histórica del cerco y posterior toma de Antequera, al margen de las crónicas o relatos de letrados ${ }^{166}$ o caballeros ${ }^{167}$ presentes, se iniciaría con los testimonios de los combatientes que regresaban a sus lugares de origen. Relatos que al transmitirse de forma oral entre una población esencialmente iletrada no han llegado hasta hoy, no obstante conocer que existieron. Al margen del mayor o menor control sobre la información que se tenía de lo que ocurría en el cerco, el resultado de la campaña de I4IO, al contrario que la de I407, fue un triunfo para las armas castellanas, por lo que las burlas al regente no tuvieron razón de $\operatorname{ser}^{168}$, y en algunas poblaciones como Sevilla, y quizá Valladolid, fue recibido como un caudillo vencedor. La victoria fue muy celebrada en los reinos de Castilla y la noticia, en un claro ejemplo de propaganda, se difundió por Navarra y Aragón, por Francia, en la corte papal o en Portugal. Los festejos organizados para celebrar la victoria castellana se engloban en lo que se ha denominado fiestas políticas, siendo algunos de sus elementos las celebraciones religiosas, la música con cantores, ministriles

164. AMPdN., CP., 238/13, carp. 12, f. 25v. En el apunte anterior al citado se señala que «... mandó dar el conçejo a los vallesteros et lançeros que fueron a la guerra este anno pasado».

165. Incluimos este apartado en un artículo cuya temática principal es otra justificándose por el hecho de que siendo una documentación esencialmente contable sus apuntes nos permiten entrever ciertas prácticas, en este caso festivas, de la sociedad castellana bajomedieval. Además, no constan más gastos del concejo de Paredes relativos a la toma de Antequera.

166. Como el relato del doctor Fernández de Cascales. CAsCALES, Francisco de: Discursos históricos de la ciudad de Murcia y de su Reino, Murcia, Academia Alfonso X el Sabio, 19804.

167. Caso de Ghillebert de Lannoy. LANNOY, Guillebert de: Voyages et ambassades de Mesire Guillebert de Lannoy, chevalier de la Toison d'or, Seigneur de Santes, Willerval, Tronchiennes, Beaumont et Wahégnies 1399-1450, Mons, Société de Bibliophiles de Mons, 1840 .

168. Me refiero a lo que ocurrió en Carmona tras la campaña de 1407, cuando las tropas castellanas fueron escarnecidas por los habitantes de la citada población tras levantar el cerco a Setenil. Véanse PÉREZ DE GuZMÁN, Fernán: op. cit., p. 300; García de SAnTA María, Álvar: Crónica, pp. 188-189. Según Sánchez Saus, Rafael: Linajes sevillanos medievales, Sevilla, Ediciones Guadalquivir, 1991, p. 46, en la actitud de Carmona hay que tener en cuenta el temor de la población a nuevos excesos de los soldados, la lucha por el poder entre los regentes y sus parciales. Además, Carmona había sido el principal núcleo de resistencia petrista. A esto hay que añadir que el infante era en aquellos momentos el jefe de la casa de Trastámara, lo que justificaría «El inconfundible clima de burla y alegría revanchista que los vencidos en contienda civil reservan para acoger los tropiezos del enemigo político triunfante». 
y los bailes, así como las corridas de toros ${ }^{169}$; la intención era difundirlo y contar con la participación de los diferentes estamentos sociales.

A lo largo de los prácticamente cinco meses que duró el asedio y conquista de Antequera la vida local giraría alrededor de la campaña militar ${ }^{170}$ y las noticias que en Paredes de Nava se tuvieron sobre la evolución del cerco a la villa musulmana debieron de ser bastante escasas, entre otras razones por la excesiva distancia que separa a las dos poblaciones. El conocimiento directo de lo que ocurría en Antequera llegaría de la mano y con la vuelta de los primeros combatientes y de los que habían desertado. Es posible que, en ambos casos, su relato cuente con una mayor dosis de objetividad que el que pudieron dar diferentes enviados del concejo de Paredes que alcanzaron la citada villa granadina, como ocurrió con el bachiller Fernando Martínez ${ }^{171}$ o con Alfonso González Serrano ${ }^{172}$, que no tomaron parte en las acciones de armas.

Noticias indirectas también debieron de tener y, sin duda, serían más interesadas como las que pudieron dar «... a Alfón Sarmiento quel conçejo le mandó yr a Valladolid a saber alguna cosa que conplía al conçejo e non falló y al conde don Fadrique que ouo de yr fasta Mojados e sopo en commo se yua para la guerra de los moros» ${ }^{173}$; el mensajero que llegó a la villa para comunicar la victoria castellana y que, aunque no se cita cuál fue, todo indicaría que se trató de la batalla de la Boca del Asno, en los comienzos del asedio a Antequera y a principios del mes de mayo de $\mathrm{I}_{4} \mathrm{IO}^{\mathrm{I74}} \mathrm{O}$ el mensaje que portó Fernando de Cuéllar, escudero del obispo de León, don Alfonso de Argüello, «... de cómo era entrada Antequera», al que se le recompensa con doscientos maravedíes por parte del concejo de Paredes de $\mathrm{Nava}^{\mathrm{175}}$. También hay noticia de que «... Juan de Paredinos escudero de don Alfón que traxo las aluises al conçejo de cómmo el infant auía vençido los moros, quel mandó dar el conçejo çient mrs restó los otros tresientos mrs» ${ }^{176}$.

Las noticias de las victorias sobre los musulmanes se acogieron con júbilo, se festejaron de diversas maneras, como en otras partes del reino ${ }^{177}$ y comportaron nuevos dispendios para las arcas municipales de Paredes de Nava. El más importante, desde un punto de vista cuantitativo, fue el gasto en toros ${ }^{178}$. Por uno de ellos «...

169. Véase LADERo QueSADA, Miguel Ángel: Las fiestas en la cultura medieval, Barcelona, Ed. Debate, 2004.

170. Al igual que en otras villas de señorío cercanas. MARTín CEA, Juan Carlos: op. cit., pp. 51-52; MARTínez So PenA, Pascual: op. cit., p. 487.

171. AMPdN., CP., 238/12, carp. 11, f. 27 r.

172. AMPdN., CP., 238/12, carp. 11, f. 29v.

173. AMPdN., CP., 238/12, carp. 11, f. 25v.

174. «Item pagué más al mensajero que traxo las nuevas del infant de la batalla de los quatroçientos mrs que conçejo le mandó dar dy yo los çiento enel mes de mayo e dióle Juan Fernández Bueno los tresientos mrs». AMPdN., CP., 238/12, carp. 11, f. 4 r.

175. AMPdN., CP., 238/12, carp. 11, f. 8r.

176. AMPdN., CP., 238/12, carp. 11, f. 25v.

177. Véase, por ejemplo, el testimonio que publica JARDIN, Jean-Pierre: «Le règne de Jean II vu depuis Murcie», Mélanges de la Casa de Velázquez, XXX/ 1 (1994), p. 221, que toma de BN., Mss. 10448, ff. 271r-278r. «Et por todos los rreynos de Castilla e de León fizieron muj grandes alegrjas desque sopieron que la villa de Antiquera hera ganada».

178. Sobre las corridas y cacerías de animales véase el apartado del mismo título en la obra de LADERO QUESADA, 
quel conçejo mandó mercar para faser alegrías por quanto nuestro sennor el infant auíe vençido alos moros» el concejo pagó trescientos cinco maravedíes, más quince de alcabala, en total trescientos veinte ${ }^{\mathrm{r} 79}$. En el otro toro el concejo se gastó quinientos cincuenta maravedíes ${ }^{180}$. A estos desembolsos hay que añadir los diez maravedíes que se pagaron a un vecino de Becerril «... porque dexó dormir las vacas con el toro de don Ferrando porque non fesiese mal»; los veintitrés que comportó cercar «... el corro do corrieron los toros» y los cuarenta que importó el trabajo de dos carniceros por matar, desollar y pesar a «... los toros que se corrieron para las alegrías del infant por cada uno toro veynte mrs, que son cuarenta mrs» ${ }^{18 \mathrm{r}}$. De acuerdo con lo expuesto, todo hace suponer que aunque se compraron dos toros, por parte del concejo, uno de ellos podía proceder de Villalón, si se atiende al topónimo del vendedor, Juan Pariente de Villalón, teniendo en cuenta también que en su traslado a Paredes habría hecho parada en Becerril de Campos antes de recalar en la citada población. En cualquier caso, todo parece indicar que el concejo paredeño se pudo resarcir, al menos en parte, con la venta de la carne y de los cueros de los toros, que supusieron doscientos cuatro y ciento sesenta maravedíes, respectivamente ${ }^{\mathrm{I} 82}$.

Otro gasto, vinculado con la victoria del infante don Fernando sobre los granadinos, que el concejo de Paredes de Nava costeó, fue el pago que hizo a «... Iohn Garçía Camesso porque fiso las danças de las espadas de las alegrías de nuestro señor el infant quando vençió los moros ${ }^{183}$. Sin embargo, ignoramos el importe de ese pago porque no se desglosa y está incluido en un abono sobre el consumo de vino de los miembros del concejo. No obstante, y según conocemos por un encargo semejante al mismo Juan García por parte del concejo de Paredes, con ocasión de la elección de don Fernando como rey de Aragón, en I4I2, «... porque guisó la dança et la fiso su ser et ordenada», recibió diez maravedíes ${ }^{184}$. En relación con esta última celebración de I4Io, y de acuerdo con lo afirmado para I4I2, todo indicaría que esa danza pudo ser colectiva y pública, que los

\footnotetext{
Miguel Ángel: Las fiestas..., pp. 140-145. En Villalón de Campos también se corrieron toros para festejar el hecho de armas, véase MARTínez SOPENA, Pascual: op. cit., p. 487.

179. AMPdN., CP., 238/12, carp. 11, f. 25V.

180. AMPdN., CP., 238/12, carp. 11, f. $26 \mathrm{v}$.

181. Los tres ejemplos en AMPdN., CP., 238/12, carp. 11, f. 26r. García-BAQUero GonzÁLez, Antonio et alii: Sevilla y la fiesta de los toros, Sevilla, Ayuntamiento de Sevilla, 1980, p. 17, destacan el carácter votivo de la fiesta. MARTíneZ CARRILLO, María de los Llanos: «Elitismo y participación popular en las fiestas medievales», Miscelánea Medieval Murciana, XVIII (1993-1994), p. 100, pone de manifiesto que en el siglo XV correr o agarrochar los toros era un «... festejo cívico ligado a las grandes celebraciones familiares de la Monarquía o algunas empresas políticas importantes». Además, destaca el protagonismo de la élite pues toro, caballo y armas eran los instrumentos de exhibición de la habilidad del hombre. Véase también el apartado 'Sobre el correr toros ' en el artículo de RodRIGO EsTEVAN, María Luz: «Juegos y festejos en la ciudad bajomedieval: sobre el correr toros en la Daroca del siglo XV», Aragón en la Edad Media, 10-11 (1993), pp. 749-752.

182. AMPdN., CP., 238/12, carp. 11, f. 21v.

183. AMPdN., CP., 238/12, carp. 11, f. 26r.

184. AMPdN., CP., 239/1, carp. 13, f. 25r. Las celebraciones de Paredes de Nava con ocasión de la elección del infante don Fernando como rey de Aragón fueron esencialmente las mismas que las que se han detallado por su victoria sobre los musulmanes: el correr toros y la danza de las espadas. Incluso los gastos por algún concepto, como los dos toros que el concejo compró en 1412 importaron 850 mrs. y los dos que se adquirieron en 1410 costaron 870 mrs.
} 
danzantes serían hombres que «... llevados por ese guía, suelen permanecer alineados, obligándose a ejecutar el mismo movimiento, dibujando y construyendo mudanzas o figuras en filas, hileras, puentes o arcos, en cadena, en círculo, coro o corro, en zig-zag, culebra o serpiente, en espiral o caracol» ${ }^{185}$.

Así pues, y en estas celebraciones, el concejo de Paredes se habría gastado novecientos cuarenta y tres maravedíes en todo lo que nos ha llegado del correr los toros y tan solo diez de la puesta en escena de la danza. Teniendo en cuenta que el concejo vendió la carne y el cuero de los toros y que por ello percibió trescientos sesenta y cuatro maravedíes, el gasto total de las celebraciones solo sería de quinientos setenta y nueve maravedíes. Cantidad muy escasa en comparación con el desembolso que supusieron las dos campañas de la guerra contra los granadinos para el concejo de Paredes de Nava a comienzos del siglo xv.

185. De los numerosos ejemplos de danzas de espadas existentes en la geografía española, desde el País Vasco con la espata-dantza, pasando por Iruecha en Soria, Redondela en Pontevedra, Todolella en Castellón, Obejo en Córdoba o las que tienen lugar en la provincia de Huelva, véase García GALLARdo, Francisco José \& AREdondo PéreZ, Herminia: «Danzas de espadas y toques de tamboril en la Sierra y el Andévalo onubenses», Iván IGLESIAS, Pedro Roxo, Susana Moreno (Coords.), Músicas e Saberes em Trânsito. Actas del XI Congreso de la SIBE, Lisboa (28-31 de octubre de 2010), Lisboa, 2012. Disponible en la red en www.sibetrans.com. 


\section{CONCLUSIONES}

La nueva fase bélica que enfrenta a castellanos y granadinos tras algo más de cincuenta años de inactividad, supuso un reto logístico, económico-fiscal, tecnológico y político, del que la monarquía saldrá reforzada. Las campañas de I407 y de I4Io dirigidas por el regente del reino, el infante don Fernando, señor de Paredes de Nava, implicaron a todo el reino, siendo la población de ciudades y villas la afectada en mayor medida. Las evidencias que se han presentado en las páginas anteriores nos llevan a afirmar que el concejo de Paredes de Nava, como otros tantos de Castilla de realengo o de señorío, contribuyó de diferentes formas a las campañas militares castellanas contra el reino nazarí de Granada durante la minoría de Juan Il. En tal sentido, se conocían pocos datos y muy dispersos de las aportaciones de Paredes de Nava y aquí creemos haber reunido un buen número que demuestran la importancia de las obligaciones de carácter señorial, la estrecha relación existente entre guerra y ciudad y entre guerra y fiscalidad -por las continuas exigencias contributivas para tal fin- o la mentalidad de algunos combatientes no profesionales, por poner unos ejemplos. Estos puntos relevantes han quedado resueltos, otros también destacables, pero de carácter menor, como el itinerario seguido por los combatientes paredeños hasta llegar a Antequera, quedan sin solucionar. Como tampoco se han podido hacer una comparación exhaustiva con las aportaciones de otros concejos o determinar qué efectos tuvieron estas contribuciones en la economía y en la sociedad paredeñas del momento, entre otras redistribuir los recursos a nivel local, bien por falta de documentación, bien por las carencias que presenta o porque son impuestos y momentos diferentes, sobre todo.

El caso de Paredes de Nava, dejando al margen a las poblaciones de Andalucía, es bastante relevante puesto que prácticamente es la única al Norte de Despeñaperros que conserva una documentación tan extensa y prolija referida a las citadas campañas, en las que tomó parte de diferentes maneras. Así, Paredes colaboró en la campaña militar de I407 por medio de la logística y las finanzas. Desde un punto de vista estrictamente económico, esta campaña militar supuso para las arcas municipales como mínimo un desembolso de 170 o25 maravedíes y como máximo 230 025. Si tomamos como referencia esta última cifra los habitantes de Paredes de Nava aportaron el o,5I por ciento del total del reino aprobado por las Cortes de Castilla.

Los preparativos para la campaña militar de I4Io comenzaron en Paredes de Nava al menos en I409. Ese año se hicieron dos alardes por orden del infante para conocer la población que podía movilizar. Don Fernando volvió a demandar de nuevo una elevada cantidad de dinero, nada menos que roo ooo maravedíes, «... para la guerra de los moros». Su visita a la villa durante el verano de I409, sin duda, facilitaría la percepción de tan importante cantidad y reduciría los recelos que despertaba ser escogido para combatir. 
La principal aportación de Paredes de Nava a la campaña contra Antequera en I4Io fue la de ciento sesenta ballesteros y lanceros divididos en dos turnos y por un tiempo de dos meses. El pago a estos combatientes se hizo con la imposición de tributos extraordinarios, tanto por la Hacienda regia como por las arcas municipales. La mayor parte, un 57 por ciento de lo recaudado correspondió a los impuestos municipales y el resto, un 43 por ciento, a los de carácter general comunes a todo el reino. El sueldo lo integraban dos partidas, el dinero diario como combatiente, que representaba el 70,98 por ciento y la cantidad satisfecha por el desplazamiento, que suponía el 29,or por ciento. Por lo que el gasto total para el concejo se elevó hasta los iıo 300 maravedíes, aunque se recaudó mucho más.

Por otro lado, la documentación estudiada deja bastante claro que la elección de combatientes no despertó mucho entusiasmo entre la población masculina de Paredes de Nava, de ahí las ausencias y las sustituciones, así como contratos posteriores. Además, y como era bastante normal entre gente que no se dedicaba al oficio de las armas, se dieron varios casos de lanceros y ballesteros paredeños que abandonaron el real castellano sin licencia. Esto motivó que a su llegada a Paredes se enfrentaran con la devolución de lo cobrado, con su prisión y con el embargo y posterior venta de sus bienes.

Las noticias sobre la evolución del cerco a Antequera que se tuvieron en Paredes de Nava debieron de ser bastante escasas. Muy pocas de primera mano y más indirectas y a través de terceros, como mensajeros. No obstante, las victorias sobre los granadinos se festejaron con toros y con danzas de espadas. 


\section{APÉNDICE DOCUMENTAL}

I4IO, s/f. Paredes de Nava

Cantidades que el concejo de Paredes de Nava mandó retener a los ballesteros y lanceros que fueron en el primer turno a la campaña de i4Io.

A-AMPdN., Cuentas de Propios, 238/ı2, Carp. II, ff. 9v-Ior y ff. 34r-v

Item que me retouieron los vallesteros e lançeros que fueron a la guerra la primera uegada que les mandó el conçejo retener a cada uno su fumazgo que son estos que aquí dirá:

Primeramente el barrio de San Juan el yerno de Juan de Castro cojedor ocho fumadgos que son a los detraer por nombre quien son.// fol. Ior Del barrio de Calleluenga Alfón Manço et Alfón García fijo de Martín García [Fuel] et Martín fijo de Juan Ferrándes de Alua et Diego de Nogal et Alfón [Conquetano] et Ferrand Gato et Juan Luengo et Juan de Cuéllar et Alfón Díes fijo de Martín Díes et Pero García yerno de Juan [Arias tachado] Yuanes et Juan yerno de Pero Boto et Juan fijo de Alfón Ferrándes converso et Pedro fijo de Juan Sanguinello et Juan Gormás et Pedro fijo de Toribio Sanguinello et Juan Chamorro que son todos díes e seys en monta çiento e sesenta mrs. (CLX)

Item del barrio de Ardagón cojedor Pero del Espada Aparisçio yerno de Martín Otero e el nieto de Garrido et Diego el yerno de Sauanillo et Juan Ximión et Françisco Franco et Juan de Respenda et Tomás de Posa et Diego Rramos que son ocho en que monta a díes mrs ochenta mrs. (LXXX)

Del barrio de Gallegos cojedor García Gil retoviéronle estas personas que se disen Ferrand Cano et Diego yerno de Diego Aparisçio et Juan de la Cal Nueua et Alfón de Mieses et Alfón Péres Alario et Diego Corbo et Juan Tomás et Pero García de Villamende et Alfón García yerno de Gonçalo García et Toribio de los Laços et Juan Merino et Pero Soria et Juan Colomo et el yerno de Diego Ferrándes Galeano et Ferrand Villarrey que son quinse monta çiento e çinquenta mrs. (CL)// fol. 34r Las rretenençias que dieron los cojedores de los barrios de los fumadgos de los que estauan en el rreal de los moros en el dicho anno de mill et quatroçientos et díes annos que los non cogieron son estos que aquí dirá en esta guisa cada barrio sobre sy.

Del barrio de Mediano:

Primeramente de Juan de Ayuela de su fumadgo díes mrs. (X)

Item de Pero Quadrado de su fumadgo díes mrs. (X)

Item de Juan de Fontecha de su fumadgo díes mrs. (X)

Item de Juan Pelas fijo de Alfón Pelas de su fumadgo díes mrs. (X)

Item de Pero Sennor de su fumadgo díes mrs. (X)

Item de Diego de Autiello de su fumadgo díes mrs. (X) 
Item de Alfón de Ribas de su fumadgo díes mrs. (X)

Item del barrio de Sant Miguel son estos que aquí dirá:

Primeramente Juan Martínes yerno de Antón Mannero de dos fumadgos veynte mrs. (XX)

Item de Françisco fijo de Gutierre Martínes de su fumadgo díes mrs. (X)

Item del yerno de Juan de Aguilar de su fumadgo díes mrs. (X)

Item de Pero Bermúdes de su fumadgo díes mrs. (X)

Item de Juan [i?] de Pino de su fumadgo díes mrs. (X)

Item de Juan Colomo de su fumadgo díes mrs. (X)

Item del fijo de Vagaroso de su fumadgo díes mrs. (X)

Item de Pero Martínes vallestero de su fumadgo díes mrs. (X)// f. 34V Item de Tomás Andrés de su fumadgo díes mrs. (X)

Item del yerno de Canmero de su fumadgo díes mrs. (X)

Los del barrio de la Fuente son estos que aquí dirá:

Primeramente de Juan de Caloca de su fumadgo díes mrs. (X)

Item de Pero yerno de Pero Péres clérigo de su fumadgo díes mrs. (X)

Item de Juan de Cuenca de su fumadgo díes mrs. (X)

Item de Juan de Sagentes de su fumadgo díes mrs. (X)

Item de Pero Monte de su fumadgo díes mrs. (X)

Item de Ferrand Cantarino de su fumadgo díes mrs. (X)

Item de Alfón Constanço de su fumadgo díes mrs. (X)

Los del barrio de Renedo son estos que aquí dirá en esta guisa:

Primeramente de Diego Lobete de su fumadgo díes mrs. (X)

Item de Ferrand Loçano de su fumadgo díes mrs. (X)

Item del yerno de Diego Lucas de su fumadgo díes mrs. (X)

Item de García Calcanar de su fumadgo díes mrs. (X)

Item de Rrodrigo Alfón soguero de su fumadgo díes mrs. (X)

Item de Pedro yerno de [¿?] de su fumadgo díes mrs. (X)

Asy monta en estos quatro barrios en las retenençias destos dichos fumadgos que me retouieron amí Juan Ferrándes Bueno de los que estauan en el real segund que desuso se contiene e está escripto por menudo cada barrio sobre sy que montó en estos fumadgos destos dichos quatro barrios tresientos et díes mrs. (CCCX)

I4IO, s/f. Paredes de Nava

Retenencias que dieron a Juan Fernández Bueno los cogedores del pecho de los combatientes que estaban en el real sobre Antequera en I4Io.

A-AMPdN., Cuentas de Propios, 238/I2, Carp. II, ff. 3IV-34r

Las rretenençias que me dieron a mi Juan Ferrándes Bueno los cogedores del pecho de a quatro mrs et medio el mrs de cabeça de los que estauan en el real 
quel conçejo les mandó retener en este dicho anno de mill et quatroçientos et díes annos son estas en esta quisa que adelant dirá.

Primeramente del barrio de Sant de Sant Juan de que fue cojedor Alfón García Laso retenencias que dio son estas en esta guisa.// f. 32r Primeramente de Pedro fijo de Pero de las Eras de cabeça nueue mrs et tres dineros que son quarenta et un mrs et ocho dineros medio. (XLI y VIII ${ }_{\mathrm{I} / 2}$ )

Item de Juan Nabo de cabeça dose mrs medio que son çinquenta e dos mrs e dos dineros medio. (LIl y $\mathrm{II}_{\mathrm{I} / 2}$ )

Item de Alfón Delgado el Moço de cabeça quatro mrs un dinero medio que son veynte e un mrs e dos dineros medio. (XXI y $\mathrm{Il}_{\mathrm{I} / 2}$ )

Item de Juan fijo de Alfón Ferrándes de Villotilla de cabeça tres mrs un dinero medio que son catorse mrs et dos dineros. (XIIIl y II)

Item de Ferrando fijo de Rrodrigo Alfón de cabeça quatro mrs VI dineros que son veynte et tres mrs et quatro dineros. (XXIII y IIII)

Item de Alfón Binejo de cabeça çinco mrs medio e dos dineros que son veynte et tres mrs et quatro dineros. (XXIII y IIII)

Item de Juan de Monçón de cabeça dos mrs medio et quatro dineros medio que son onse mrs et medio dinero. (XI y $1 / 2$ )

Item de Alfón Monçón de lo qual copo de su padre de cabeça dos mrs et seys dineros que son onse mrs et siete dineros. (XI y VII)

Item de Alfón Çapatero de cabeça dos mrs medio e seys dineros que son onse mrs e siete dineros. (XI y VII)

Las rretenencias del barrio de la Fuente de los del real son estas que aquí dirá en esta guisa:

Primeramente de Juan García de Cuenca de cabeça díes et siete mrs et seys dineros que son (borrado) sesenta et nuueve mrs e dos dineros. (LXIX y II)

Item de Juan de Sagentes de cabeça un dinero mesio que son siete dineros medio. (VII d $\mathrm{r}_{\mathrm{r} / 2}$ )

Item de Juan de Caloca seys dineros de cabeça que son dos mrs e siete dineros. (II y VII)

Item de Pero Briuejo de cabeça seys mrs medio que son veynte et siete mrs. (XXVII)

Las rretenencias del barrio de Renedo de los que fueron al rreal son estas en esta guisa:

Primeramente de Diego Lobete de cabeça quatro mrs e ocho dineros medio que son veynte et un mrs e çinco dineros. (XXI y V)

Item de Ferrand Loçano de cabeça quatro mrs seys dineros medio que son veynte et un mrs. (XXI)

Item del yerno de Diego Lucas de cabeça nueue mrs et quatro dineros et medio que son quarenta et dos mrs et un cornado. (XLIl y I cor) 
Item de García de Calcanar de cabeça dos mrs medio et quatro dineros medio que son onse mrs. (XI)// f. 32v Item de Pero García yerno de [¿?] de cabeça un mrs e çinco dineros medio que son seys mrs e ocho dineros medio. (VI y VIII ${ }_{\mathrm{I} / 2}$ )

Item de Rodrigo Alfón soguero de cabeça ocho mrs et dos dineros que son treynta et siete mrs. (XXXVII)

Item de Juan de Caloca de cabeça tres mrs et siete dineros que son díes et seys mrs et quatro dineros. (XVI y IIII)

Las rretencias del barrio de Mediano de los que fueron al real son estas que aquí dirá en esta guisa:

Primeramente de Juan de Fontecha de cabeça díes et seys mrs et dos dineros medio que son setenta et tres mrs e un dinero. (LXXIII y I)

Item de Juan de Ayuela de cabeça siete mrs et tres dineros que son treynta et dos mrs et ocho dineros medio. (XXXII y $\mathrm{VIII}_{\mathrm{r} / 2}$ )

Item de Alfón fijo de Alfón García costaron de cabeça un mrs et çinco dineros que son seys mrs et siete dineros medio. $\left(\mathrm{VI}\right.$ y $\left.\mathrm{VII}_{\mathrm{r} / 2}\right)$

Item de Alfón de Ribas de cabeça díes mrs e siete dineros medio que son quarenta et ochio mrs et dos cornados. (IlL y II)

Item de García de Calcanar de cabeça un mrs que son quatro mrs $\mathrm{V}$ dineros. (IIII y V)

Item de Juan de Caloca de cabeça $\mathrm{V}$ dineros que son dos mrs siete dineros medio. ( $\mathrm{Il} \mathrm{y} \mathrm{VII}_{\mathrm{I} / 2}$ )

Item de Pero Quadrado de cabeça catorse mrs et çinco dineros medio que son sesenta et seys mrs et çinco dineros. (LXVI y V)

Item de Diego de Autiello de cabeça un mrs et quatro dineros medio que son seys mrs et tres dineros. (VI y III)

Item de Martín fijo de Juan Péres de cabeça un mrs que son quatro mrs çinco dineros. (IIIl y V)

Item de Juan de Pelas fijo de Alfón Pelas de cabeça ocho mrs et nueue dineros que son quarenta mrs medio dinero. (XL y $1 / 2$ )

Item de Pedro yerno de Pero Martínes de Tramaya de cabeça dos mrs et un dinero medio que son díes mrs et siete dineros. (X y VII)

Item de Pero Sennor de cabeça nueue mrs que son quarenta mrs et çinco dineros. (XL y V)

Item de Juan García de Cuenca un mrs e un dinero que son çinco mrs et medio dinero. $\left(\mathrm{V} \mathrm{y}^{1 / 2}\right.$ )// f. 33 r Las rretenencias del barrio de Sant Miguel de los vallesteros et lançeros que fueron a la guerra de los moros este dicho anno son estas que dirá en esta guisa:

Primeramente de Pero Martínes vallestero de cabeça tres mrs IIII dineros que son quinse mrs et tres dineros. (XV y III)

Item de Juan Martínes yerno de Antón Mannero de cabeça tres mrs e tres dineros que son catorse mrs e ocho dineros medio. (XIIII y VIII $\mathrm{I} / 2_{2}$ ) 
Item de Juan Sánches de Pinno de cabeça tres mrs Illl dineros medio que son quinse mrs e çinco dineros medio. $\left(\mathrm{XV} \mathrm{y} \mathrm{V}_{\mathrm{r} / 2}\right)$

Item de Tomás Andrés de cabeça dos mrs e un dinero que son nueue mrs quatro dineros medio. (IX y $\mathrm{IIII}_{\mathrm{I} / 2}$ )

Item de Juan Colomo de cabeça dos dineros que son nueve dineros. (IX d)

Item de Ferrando fijo de Gutierre Martínes de cabeça dos mrs e quatro dineros que son díes mrs et ocho dineros. (X y VIII)

Las rretencias del barrio de Calleluenga de los que fueron al rreal este dicho anno son estas que aquí dirá en esta guisa:

Primeramente de Tomás Andrés de cebeça quatro mrs e çinco dineros medio que son veynte mrs et çinco dineros. (XX y V)

Item de Alfón Maço de cabeça tres mrs J dinero medio que son catorse mrs e dos dineros. (XIIII y II)

Item de Françisco Gato de cabeça siete mrs dos dineros medio que son treynta e dos mrs çinco dineros. (XXXIl y V)

Item de Pero García yerno de Juan Yannes de cabeça díes e seys mrs J dinero medio que son setenta e dos mrs çinco dineros. (LXXIl y V)

Item de Juan yerno de Juan Péres de cabeça un mrs quatro dineros medio que son seys mrs e çinco dineros. (VI y V)

Item de Juan de Sagentes de cabeça seys mrs çinco dineros que son veynte nueue mrs dos dineros. (IXXX y II)

Item de Alfón Díes fijo de Martín Díes de cabeça trese mrs Illl dineros que son sesenta mrs e tres dineros. (LX y III)

Item de Françisco fijo de Antón Franco de cabeça tres mrs çinco dineros que son quinse mrs siete dineros. (XV y VII)

Item de García Fuel de cabeça tres mrs çinco dineros medio que son quinse mrs nueue dineros medio. $\left(\mathrm{XV}\right.$ y $\left.\mathrm{IX}_{\mathrm{I} / 2}\right)$

Item de $\mathrm{D}$. de Nogal de cabeça ocho mrs nueue dineros que son quarenta mrs medio dinero. (LX y $1 / 2)$

Item de García Fidalgo de cabeça díes mrs que son quarenta et çinco mrs. (XLV)

Item de Diego Lobete de cabeça nueue mrs que son quarenta e çinco dinero. $(\mathrm{XLV} \mathrm{d})$

Item de Juan Ximón de cabeça seys mrs medio dinero que son veynte et siete mrs dos dineros. (XXVII y II)

Item de Juan Chamorro de cabeça siete mrs quatro dineros que son treynta e tres mrs tres dineros. (XXXIIl y III)// f. 33v Item de Pero García fijo de Alfón Ferrándes lançero de cabeça onse mrs siete dineros que son çinquenta e dos mrs e dos dineros. (LIl y II)

Item de Pedro criado de Pero Moro de cabeça çinco mrs çinco dineros que son beynte quatro mrs siete dineros. (XXIIll y VII)

Item de Diego Corbo siete dineros de cabeça que son tres mrs un dinero medio. (IIl y $\mathrm{I}_{\mathrm{r} / 2}$ ) 
Item de Pero Echador fijo de Juan Echador de cabeça un dinero que son quatro dineros medio. (IIII $\mathrm{d}_{\mathrm{I} / 2}$ )

Item de Garrido nieto de Pero Garrido de cabeça un mrs dos dineros que son çinco mrs quatro dineros. (V y IIII)

Las rretenencias del barrio de Ardagón de los que fueron al rreal este dicho anno son estas que aquí dirá en esta guisa:

Primeramente de Juan Ximón de cabeça nueue mrs tres dineros medio que son quarenta dos mrs. (XLII)

Item de Toribio de Posa de cabeça un mrs siete dineros que son ocho mrs un dinero medio. (VII y $\mathrm{I}_{\mathrm{I} / 2}$ )

Item del yerno de Martín Otero de cabeça dose mrs un dinero que son çinquenta quatro mrs quatro dineros medio. (LIIIl y $111 I_{\mathrm{I} / 2}$ )

Item de Juan de Respenda de cabeça nueue mrs ocho dineros medio que son quarenta quatro mrs e un dinero. (XLIIII y I)

Item de Françisco nieto de Antón Franco de cabeça dos mrs çinco dineros medio que son dose mrs. (XII)

Item de Garrido yerno de Martín Díes de cabeça ocho mrs que son treynta et ocho mrs. (XXXVIII)

Item que ouo de pagar más este Pero Garrido de lo de Diego Arral treynta tres mrs. (XXXIII)

Item de Diego yerno de Rauanilla de cabeça ocho dineros que son tres mrs seys dineros. (Ill y VI)

Item del yerno de Antón Manneto de cabeça un mrs çinco dineros que son seys mrs siete dineros medio. ( $\mathrm{VI}$ y $\mathrm{VII}_{\mathrm{I} / 2}$ )

Item de Juan Luengo de cabeça un mrs çinco dineros que son seys mrs siete dineros medio. (VI y $\mathrm{VII}_{\mathrm{I} / 2}$ )

Las retenencias del barrio de Gallegos de los que fueron al real este dicho anno son estas que aquí dirá en esta guisa:

Primeramente de Ferrand Cano de cabeça ocho dineros medio que son tres mrs siete dineros. (IIl y VII)

Item de Diego yerno de Aparisçio de cabeça siete mrs tres dineros que son treynta dos mrs ocho dineros medio. (XXXIl y VIII ${ }_{\mathrm{I} / 2}$ )

Item de Juan Martínes de la Cal Nueva de cabeça ocho mrs nueue dineros que son quarenta mrs medio dinero. (XL y $1 / 2$ )

Item de Alfón de Mieres de cabeça çinco mrs tres dineros que son veynte tres mrs ocho dineros medio. (XXIIl y VIII $\mathrm{I} / 2_{2}$ )

Item de Alfón Péres Alario de cabeça quinse mrs nueue dineros que son setenta un mrs medio dinero. (LXXI y $1 / 2$ )

Item de Pero García yerno de Galeano de cabeça un mrs medio dinero que son quatro mrs siete dineros. (IIIl y VII)

Item de Diego Corbo de cabeça quatro mrs nueue dineros medio que son veynte dos mrs et çinco dineros. (XXII y V) 
Item de Juan Colomo de cabeça un mrs çinco dineros que son siete mrs siete dineros medio. (VII y $\mathrm{VII}_{\mathrm{I} / 2}$ )

Item de Juan Tomás de cabeça seys mrs quatro dineros medio que son veynte e siete mrs et dos dineros medio. (XXVII y $\mathrm{II}_{\mathrm{I} / 2}$ )

Item de Pero García de Villamende de cabeça onse mrs seys dineros que son çinquenta et dos e dos dineros. (LII y II)

Item del yerno de Gonçalo García de cabeça dos dineros medio que son un mrs un dinero medio. ( $\left.\mathrm{I}_{\mathrm{y} \mathrm{I}_{\mathrm{I} / 2}}\right) / / \mathrm{f}$. $34 \mathrm{r}$ Item de Toribio de los Laços de cabeça dos mrs quatro dineros medio que son onse mrs et dos dineros medio. $\left(\mathrm{XI}\right.$ y $\mathrm{II}_{\mathrm{I} / 2}$ )

Asy montan estas sobredichas rretenençias de los dichos vallesteros et lançeros que estodieron en la dicha guerra el dicho anno de mill et quatroçientos et díes annos que non pagaron pecho segund de suso se contiene et está escripto por menudo que montó en el pecho que asy sotouieron los dichos vallesteros et lançeros el dicho anno dos mill et nueue mrs et quatro dineros medio. (MMIX y $\operatorname{lll}_{\mathrm{t} / 2}$ ) 


\section{BIBLIOGRAFÍA}

Abellán PéRez, Juan: Diplomatario del Reino de Granada. Documentos de Juan Il de Castilla (I407-I454) del Archivo Municipal de Jerez de la Frontera, en Monumenta Regni Granatensis Historica. Diplomata, Granada, Editorial Universidad de Granada, 20II.

AbelLÁn Pérez, Juan: «La presencia de Jerez de la Frontera en la conquista de Antequera», Estudios sobre Patrimonio, Cultura y Ciencias Medievales, I5 (2013), pp. I9-36.

ABELLÁN PÉREZ, Juan: «Jerez y la frontera occidental castellano-granadina en vísperas de la conquista de Antequera», Estudios de Frontera 9. Economía, derecho y sociedad en la frontera. Homenaje a Emilio Molina López, Francisco Toro Ceballos y José Rodríguez Molina (Coordinadores), Alcalá la Real, Diputación Provincial de Jaén, 20I4, pp. 43-54.

Agudelo Herrero, Joaquín \& JimÉnez Aguilar, María Dolores: «Las milicias del concejo de Sevilla en el contexto del ejército medieval», La organización militar en los siglos XV y xvI. Actas de las II Jornadas Nacionales de Historia Militar, Málaga, Cátedra «General Castaños», I993, pp. 243-248.

ARIAS GullLÉN, Fernando: Guerra y fortalecimiento del poder regio en Castilla. El reinado de Alfonso XI (I3I2-I35O), Madrid, CSIC-Ministerio de Defensa, 2012.

BELLO LEÓN, Juan Manuel: «Las milicias concejiles castellanas a finales de la Edad Media. Un estado de la cuestión y algunos datos para contribuir a su estudio», Medievalismo, I9 (2009), pp. 287-33I.

BERNAL ESTÉVEZ, Ángel: «Las armas como concepto fiscal y de diferenciación social en la Baja Edad Media (Aplicación al caso de Ciudad Rodrigo)», Gladius. Etudes sur les armes anciennes, $l$ 'armament, $l$ 'art militaire et la vie culturelle en Orient et Occident. Primer Simposio Nacional sobre «Las armas en la Historia» (marzo 1983), Cáceres, I988, pp. 2I-30.

CAÑAs GÁlvez, Francisco de Paula: «La Casa del Infante Fernando de Castilla: corte, poder y representación político-institucional en el ocaso del Medievo (I385-I408)», Boletín de la Real Academia de la Historia, CCXIII/ I (2016), pp. 9-108.

Cascales, Francisco de: Discursos históricos de la ciudad de Murcia y de su Reino, Murcia, Academia Alfonso X el Sabio, I9804.

Collantes de Terán Delorme, Francisco: Archivo Municipal de Sevilla. Inventario de los papeles del Mayordomazgo del siglo XV (I4OI-I4I6), vol. I, Sevilla, Ayuntamiento de Sevilla, I972.

Contreras Gay, José: «La importancia histórica de las Milicias Concejiles en la guerra fronteriza y su influencia en la Edad Moderna», Estudios de Frontera. Alcalá la Real y el Arcipreste de Hita, (Francisco Toro Ceballos y José Rodríguez Molina, coords.), Jaén, Diputación Provincial de Jaén, I996, pp. I2I-I34.

Dıos, Salustiano de: «Ordenanzas del Consejo Real de Castilla (I385-I490)», Historia. Instituciones. Documentos, 7 (1980), pp. 269-320.

Dıos, Salustiano de: Fuentes para el estudio del Consejo Real de Castilla, Salamanca, Diputación de Salamanca, I986.

Franco Silva, Alfonso: «El proceso de señorialización de las tierras de palentinas en la Baja Edad Media. El caso del Condado de Saldaña», Señores y señoríos (siglos XIV-XV), Jaén, Universidad de Jaén, I997, pp. 195-215.

Fuente Pérez, María Jesús: «Sobre pechos y pecheros de un concejo medieval. Paredes de Nava», Espacio, Tiempo y Forma, Serie III, Historia Medieval, 5 (1992), pp. 39-64.

Fuente PÉrez, María Jesús: «Fuegos fiscales y fuegos reales. Paredes de Nava en el siglo xV», En la España Medieval, I6 (I993), pp. 83-95. 
Fuente Pérez, María Jesús: «Los inicios de la contabilidad municipal en Castilla. Paredes de Nava (1386-1396)», Espacio, Tiempo y Forma, Serie III, Historia Medieval, iI (I998), pp. 6I-84.

Fuente Pérez, María Jesús: «Las cargas reales de un concejo de señorío. La villa de Paredes de Nava en la Baja Edad Media», Historia. Instituciones. Documentos, 27 (2000), pp. 55-74.

García de SAnta María, Álvar: Le parti inedite della «Crónica de Juan II» di Álvar García de Santa María, Edizione critica, introduzione e note a cura di Donatella Ferro, Venezia, Consiglio Nazionale delle Richerche [Gruppo Studi d'Ispanistica], I972.

García de Santa María, Álvar: Crónica de Juan II de Castilla, Edición de Juan de Mata Carriazo y Arroquia, Madrid, Real Academia de la Historia, i982.

García Gallardo, Francisco José \& Aredondo Pérez, Herminia: «Danzas de espadas y toques de tamboril en la Sierra y el Andévalo onubenses», Iván Iglesias, Pedro Roxo, Susana Moreno (Coords.), Músicas e Saberes em Trânsito. Actas del XI Congreso de la SIBE, Lisboa (28-3I de octubre de 20Io), Lisboa, 20I2. Disponible en la red en www. sibetrans.com.

García-Baquero González, Antonio, Romero de Solís, Antonio \& Vázquez Parlade, Ignacio: Sevilla y la fiesta de los toros, Sevilla, Ayuntamiento de Sevilla, I980.

García Fitz, Francisco: «La didáctica militar en la literatura castellana (segunda mitad del siglo xill y primera del XIv)», Anuario de Estudios Medievales, I9 (I989), pp. 27I-283.

García Fitz, Francisco: «La organización militar en Castilla y León (siglos XI al xilı)», Conquistar y defender. Los recursos militares en la Edad Media Hispánica, en Revista de Historia Militar, año XLV, n. ${ }^{\circ}$ extraordinario, (200I), pp. 6I-II8.

García Fitz, Francisco: «'Las guerras de cada día’ En la Castilla del siglo xiv», Edad Media. Revista de Historia, 8 (2007a), pp. I45-I8I.

GARcía Fitz, Francisco: «La composición de los ejércitos medievales», La guerra en la Edad Media: XVII Semana de Estudios Medievales, Nájera, del 3i de julio al 4 de agosto de 2006, Blas Casado Quintanilla y José Ignacio de la PeÑa Duarte (ed.), Nájera, Instituto de Estudios Riojanos, 2007b, pp. 85-I46.

GonZÁlez JıMÉNEZ, Manuel: «Las milicias concejiles andaluzas (siglos XIII-Xv)», La organización militar en los siglos XV y XVI. Actas de las II Jornadas Nacionales de Historia Militar, Málaga, Cátedra «General Castaños», I993, pp. 227-24I.

GonZÁlez SÁnCHEZ, Santiago: Las aportaciones de Jerez de la Frontera a la campaña de Antequera. Colección documental de las Actas Capitulares, Sevilla, Publidisa, 20 Ir.

González SÁnchez, Santiago: Fernando I, regente de Castilla y rey de Aragón (I407-I4I6), Gijón, Ed. Trea, 2012.

GonZÁlez SÁNCHEZ, Santiago: «Los obispos castellanos en los inicios del siglo Xv (I407I420)», Estudios sobre Patrimonio, Cultura y Ciencias Medievales, I5 (2013), pp. I87-2I4.

GONZÁlEZ SÁNCHEZ, Santiago: Los recursos militares de la monarquía castellana a comienzos del siglo XV. Las campañas militares del infante don Fernando: Setenil y Antequera (I407I4IO), Madrid, Comité Español de Ciencias Históricas-Dykinson, 2016.

GoÑ Gaztambide, José: Historia de la bula de cruzada en España, Vitoria, Victoriensia: Publicaciones del Seminario de Vitoria, I958.

Groizard y Coronado, Carlos: «Las milicias locales en la Edad Media. La compañía de ballesteros de Calahorra», Boletín de la Real Academia de la Historia, LV (I909), pp. 359-362.

Guadalupe Beraza, María Luisa: Diezmos de la sede toledana y rentas de la mesa arzobispal (Siglo XV), Salamanca, Universidad de Salamanca, 1972.

JARDIN, Jean-Pierre: «Le règne de Jean Il vu depuis Murcie», Mélanges de la Casa de Velázquez, XXX/ I (I994), pp. 207-225. 
Ladero Quesada, Miguel Ángel: La Hacienda Real de Castilla en el siglo xv, La Laguna, Universidad de La Laguna, I973.

Ladero Quesada, Miguel Ángel: «La organización militar de la Corona de Castilla en la Baja Edad Media», Castillos medievales del Reino de León, León, Hullera Vasco-Leonesa, I989, pp. II-34.

Ladero Quesada, Miguel Ángel: «Fiscalidad regia y génesis del Estado en la Corona de Castilla (I252-I504)», Espacio, Tiempo y Forma, Serie III, Historia Medieval, 4 (I99I), pp. 95-I35.

LAdERo QuesadA, Miguel Ángel: «Formación y funcionamiento de las huestes reales en Castilla durante el siglo XV», La organización militar en los siglos XV y XVI. Actas de las II Jornadas Nacionales de Historia Militar, Málaga, Cátedra «General Castaños», I993, pp. I6I-I72.

LAdero Quesada, Miguel Ángel: Las fiestas en la cultura medieval, Barcelona, Ed. Debate, 2004.

Ladero Quesada, Miguel Ángel: «Baja Edad Media», Historia Militar de España, Dirigida por Hugo O' Donnell, Edad Media, Tomo Il, Miguel Ángel Ladero Quesada (Coordinador), Madrid, Ministerio de Defensa-Laberinto, 20Io, pp. 217-378.

LAdERo QueSAdA, Miguel Ángel: Fiscalidad y poder real en Castilla (I252-I369), Madrid, Real Academia de la Historia, 20II.

Lannoy, Guillebert de: Voyages et ambassades de Mesire Guillebert de Lannoy, chevalier de la Toison d'or, Seigneur de Santes, Willerval, Tronchiennes, Beaumont et Wahégnies 1399I450, Mons, Société de Bibliophiles de Mons, I840.

López de Ayala, Pero: Crónicas. Crónica del rey don Juan. Primero de Castilla y de León, Edición, prólogo y notas de José Luis MarTín, Barcelona, Ed. Planeta, I99I.

Martín CeA, Juan Carlos: El mundo rural castellano a fines de la Edad Media. El ejemplo de Paredes de Nava en el siglo XV, Valladolid, Junta de Castilla y León, I99I.

Martínez CARrillo, María de los Llanos: «Elitismo y participación popular en las fiestas medievales», Miscelánea Medieval Murciana, XVIII (I993-I994), pp. 95-Io8.

Martínez Marina, Francisco: Teoría de las Cortes o grandes juntas nacionales de los reinos de Castilla y León, ed. de José Manuel Pérez Prendes, vol. III, Madrid, I979 (I. ${ }^{a}$ ed. Madrid, I820).

Martínez Sopena, Pascual: «La conquête d'Antequera (I4IO). Réflexions sur la perception de la guerre dans la Castille du bas Moyen Âge», Diane de Chamboduc De SAint Pulgent, Marie Dejoux (ed.), La Fabrique des sociétés médiévales méditerranéennes. Les Moyen Âge de François Menant, Paris, Éditions de la Sorbonne, 20I8, pp. 497-488.

Menjot, Denis: «El peso de la guerra en la economía murciana: el ejemplo de la campaña de I407-I408 contra Granada», Fiscalidad y sociedad. Los murcianos y el impuesto en la Baja Edad Media, Murcia, Academia Alfonso X el Sabio, I986, pp. I39-I80.

Mitre FernándeZ, Emilio: «Un apunte sobre Don Fernando de Antequera y el señorío de Paredes de Nava», Estudios en homenaje a don Claudio Sánchez-Albornoz en sus 90 años. Anexos de Cuadernos de Historia de España, vol. IV (I986), pp. 283-288.

Mitre FernáNDEZ, Emilio: «Implantación señorial y resistencia al régimen señorial en tierras de Palencia en la época Trastámara», Actas del I Congreso de Historia de Palencia. Tomo II. Fuentes documentales y Edad Media, Palencia, Diputación Provincial de Palencia, I987, pp. 309-324.

Montes Romero-CAmacho, Isabel: «Una nueva estrategia para una vieja guerra. La preparación en Sevilla de la campaña de Antequera (I4Io)», Historia. Instituciones. Documentos, 36 (2009), pp. 269-3I2. 
Moxó y Ortiz de Villajos, Salvador de: «El Derecho militar en la España cristiana Medieval», Revista Española de Derecho Militar, I2 (196I), pp. 9-59.

MuÑoz Gómez, Víctor: «La adquisición de dominios señoriales en la Castilla bajomedieval. Fernando de Antequera y Paredes de Nava (I380-I408)», Actas del III Simposio Internacional de Jóvenes Medievalistas Lorca 2006, Juan Francisco JimÉnez AlCÁZAR, Juan Leonardo Soler Milla y Jorge OrtuÑo Molina (Eds. científicos), Murcia, Universidad de MurciaAyto. Lorca-Real Academia Alfonso X el Sabio-Fundación Cajamurcia-Lorcatur-SEEM, 2008, pp. I2I-I32.

MuÑoz Gómez, Víctor: «Bandos urbanos y pacificación señorial en la Castilla bajomedieval: Paredes de Nava y Fernando de Antequera (I400-I4I6)», Anuario de Estudios Medievales, 39/ 2 (2009), pp. 667-70I.

MuÑoz GómEz, Víctor: «El concejo de Peñafiel. Gobierno y sociedad en una villa vallisoletana en la Edad Media», Miscelánea Medieval Murciana, XXXIV (20I0), pp. 7I-8I.

MuÑoz Gómez, Víctor: El poder señorial de Fernando «el de Antequera» y los de su Casa. Señorío, redes clientelares y sociedad feudal en Castilla durante la Baja Edad Media, Madrid, CSIC, 2018.

Nieto Soria, José Manuel: Iglesia y génesis del Estado Moderno en Castilla (1369-I480), Madrid, Universidad Complutense, I993.

Ortego Rico, Pablo: «Guerra y paz como fundamentos legitimadores de la exacción fiscal: siglos Xili-XV», A. Arranz GuZmán, M. P. RÁbade Obradó \& Ó. Villarroel González, (coords.), Guerra y paz en la Edad Media, Madrid, Silex, 2013, pp. 67-I07.

Ortego Rico, Pablo: «Pedido» regio y repartimientos en Castilla: una aproximación a partir del ejemplo del Arzobispado de Toledo (I399-I476)», Baetica, 36-37 (20I4-2015), pp. II9-I56.

PARReÑo CASAdo, Manuel: «Las milicias de Sevilla», La organización militar en los siglos XV y XVI. Actas de las II Jornadas Nacionales de Historia Militar, Málaga, Cátedra «General Castaños», I993, pp. 248-252.

Pazos y Vela-Hidalgo, José de: Peñafiel. Memoria histórica, Salamanca, I88o. Hay Copia digital. Valladolid, Junta de Castilla y León. Consejería de Cultura y Turismo, 2009-20Io.

Peral, Santiago, Robles, José A, CARlón, Concepción y Ausín, Margarita: «Las Cuentas de Propios del Archivo de Paredes de Nava y su ordenación», Publicaciones de la Institución Tello Téllez de Meneses, 64 (I993), pp. 6II-6I9.

Pérez de GuZMán, Fernán: Crónica del serenísimo príncipe don Juan, segundo rey deste nombre en Castilla y León, escrita por el noble y muy prudente caballero Fernán Pérez de Guzmán, Señor de Batres, del su Consejo, Biblioteca de Autores Españoles, Ordenada por don Cayetano Rosell, LXVIII/ II, Madrid, I953.

Reglero de la Fuente, Carlos: «El poblamiento del Noreste de la cuenca del Duero en el siglo xV», Hispania, LV/ 190 (I995), pp. 425-493.

Rodrigo Estevan, María Luz: «Juegos y festejos en la ciudad bajomedieval: sobre el correr toros en la Daroca del siglo xv», Aragón en la Edad Media, IO-II (I993), pp. 749-752.

Rodríguez Molina, José Luis: «El diezmo eclesiástico en el valle del Guadalquivir, su utilidad para el estudio de la Historia Económica», Actas del I Congreso de Historia de Andalucía, vol. I, Córdoba, Publicaciones del Monte de Piedad y Caja de Ahorros de Córdoba, I978, pp. 429-434.

Romero Romero, Francisco José: Sevilla y los pedidos de Cortes en el siglo xv, Sevilla, Ayuntamiento de Sevilla ICAS, 1997. 
SÁNCHEZ SAUS, Rafael: «Las milicias concejiles y su actuación exterior: Sevilla y la guerra de Granada (I430-I439)», En la España Medieval. La ciudad hispánica durante los siglos XIII al XVI (III) (I987), pp. 393-4I8.

SÁNCHEZ SAUS, Rafael: Linajes sevillanos medievales, Sevilla, Ediciones Guadalquivir, I99I.

SÁNchez Saus, Rafael \& Martín Gutiérrez, Emilio, «Ordenanzas jerezanas del siglo xv sobre la milicia concejil y la frontera de Granada», Historia. Instituciones. Documentos, 28 (200I), pp. 377-390.

SÁnchez SaUs, Rafael \& OCAÑa Erdozain, Alberto: «Armamento y fortificación. (Siglos XI a xv)», Historia Militar de España, Dirigida por Hugo O'Donnell, Edad Media, Tomo Il, Miguel Ángel Ladero Quesada (Coordinador), Madrid, Ministerio de DefensaLaberinto, 20Io, pp. 379-4I2.

SAnZ Fuentes, María Josefa: Colección diplomática del concejo de Écija (I263-I474), vols. III y IV, Sevilla, I976.

Tenorio Cerero, Nicolás: «Las milicias de Sevilla», Revista de Archivos, Bibliotecas y Museos, $3^{\text {a }}$ época, XVII (1907), pp. 222-263. Publicado con el título Las milicias de Sevilla, en Tres obras sobre la Sevilla del siglo XIV, Introducción y selección de textos de Deborah KIRSCHBERG \& Francisco García Fitz, Sevilla, Ayuntamiento de Sevilla ICAS, 2009, pp. I-44.

Teresa León, Tomás: «De nuestros archivos. Archivo Municipal de Paredes de Nava», Publicaciones de la Institución Tello Téllez de Meneses, 8 (I952), pp. 5-26.

TORres Fontes, Juan: «La caballería de alarde murciana en el siglo XV», Anuario de Historia del Derecho Español, XXXVIII (I968), pp. 3I-86.

Triano Milán, José Manuel: La llamada del rey y el auxilio del reino. Del pedido regio a las contribuciones de la Santa Hermandad (I406-I498), Sevilla, Universidad de Sevilla, 2018.

Vilaplana Gisbert, María Victoria J.: Documentos de la minoría de Juan II. La Regencia de Don Fernando de Antequera, CODOM, vol. XV, Murcia, Academia Alfonso X el Sabio, I993.

Villaplana, María Asunción: «Un ajuste de cuentas del alcabalero mayor de Sevilla Pedro Ortiz (I420)», Historia. Instituciones. Documentos, I (1974), pp. 4I7-50I.

VILLARRoel GonZÁlez, Óscar: Las relaciones monarquía-Iglesia en época de Juan II de Castilla (I406-I454), vol. I, Madrid, Universidad Complutense, 2007. 
Calidad de Revistas

científicas Españolas

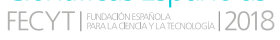

SERIE III HISTORIA MEDIEVAL

REVISTA DE LA FACULTAD DE GEOGRAFİA E HISTORIA
AÑO 2021

ISSN: 0214-9745

E-ISSN 2340-1362

\section{4 \\ issacio. \\ TIEMPO \\ Y FORMA}

\section{Volumen I}

\section{Artículos · Articles}

15 Patricia A. Argüelles Álvarez

Peligros, inseguridades y problemas del viajero visigodo

37 Carmen Barceló, Ana labarta, Josep Benedito \& José M. MELCHOR

Cuatro cerámicas con epigrafía árabe del Museu de Borriana

65 CARlos BARQuero Goñ

Organización de la Orden de San Juan en Castilla durante los siglos XII y XIII

113 Francisco de Paula Cañas Gálvez

Una infanta de Navarra en la corte de Castilla: escenarios políticos en torno a la configuración y evolución del Hostal y la casa de Blanca de Trastámara, Princesa de Asturias (1424-†1464)

\section{David Caramazana Malia}

Las promociones artísticas de Alonso de Ejea, arzobispo y administrador perpetuo de la Archidiócesis de Sevilla y patriarca de Constantinopla (1403-1417)

\section{Pedro Castillo Maldonado}

Privilegios episcopales: la inviolabilidad de los obispos visigóticos y el delito de lesa majestad

\section{MÁxIMO DIAGO HERNANDO}

Alonso de Fonseca, Obispo de Ávila, Cuenca y Osma, y el ascenso de un linaje de exiliados portugueses en la Castilla de los siglos XV y XVI

\section{Antonio PIO dI Cosmo}

Santa Brigida ed il Monte Gargano: un paesaggio dell'anima. La descrizione dell'ambiente come stratagemma d'ammaestramento morale

\section{FERRAN ESQUILACHE}

La 'fila' de agua valenciana y otras medidas de aforo. La verdadera naturaleza de un sistema de medición de caudales de origen andalusí

\section{Alejandro Esteban Álvarez}

Habices del Reino de Granada averiguados en 1528 y 1531: la țā'a nazarí de Órgiva (Alpujarra)

\section{JaVier Gómez Gómez \& IÑAKı MARTín VISO}

Rationes y decimas: evidencias sobre la gestión de las sernas en el siglo XI en el noroeste de la Península Ibérica
383 SANTIAGO GONZÁLEZ SÁNCHEZ

Aportaciones de Paredes de Nava a las campañas militares de Infante Don Fernando, señor de la villa y regente de Castilla, contra el Reino Nazarí de Granada en 1407 y en 1410

429 ANTONI LLIBRER ESCRIG

Una máquina para la industria medieval. Los batanes del sur valenciano: integración y negocio. Nuevas aportaciones (1490-1502)

455 José Miguel López Villalba Comunicación escrita y oral de la ordenanza municipa (siglos XV-XVI)

501 Emilio Martín Gutiérrez

El aprovechamiento de los recursos naturales: la grana en Andalucía occidental durante el siglo XV

\section{Volumen II}

537 VERA-CRuz Miranda MENACHO

$(1421-1461)$

Las finanzas de un heredero: Carlos de Aragón y Navarra

569 Raúl Morales Muñoz

Hacia una revalorización del conciliarismo hispano bajomedieval: el Defensorium Trium Conclusionum de Alfonso de Madrigal

605 David Nogales Rincón

Enrique III de Castilla (1390-1406) y la indagación de rentas: un proyecto regio para la búsqueda de mineros y tesoros a inicios de cuatrocientos

6.7.7 Gonzalo Oliva Manso

Seisenes y novenes. Tiempos de calma para la moneda castellano-leonesa (1282-1312)

685 Alberto Peña Fernández y Manuel García Alonso Una inscripción medieval inédita en la iglesia de San Miguel de Aguayo (Cantabria)

713 RODRIGO POUSA DIÉGUEZ

Configuración institucional de una villa costera: Muros en el tránsito de la Edad Media a la Edad Moderna

\subsection{JuAn A. Prieto Sayagués}

Las profesiones femeninas de la nobleza y de las oligarquías urbanas en la Castilla bajomedieval. Causas, dinámicas, privilegios y donaciones 


\section{4}

\section{ESPACIO,}

\section{TIEMPO}

Y FORMA

UกED

SERIE III HISTORIA MEDIEVAL

REVISTA DE LA FACULTAD DE GEOGRAFÍA E HISTORIA

815 María del Pilar Rábade Obradó

El miedo a la Inquisición en la Castilla de los Reyes Católicos

84.5 Carlos Manuel Reglero de la Fuente

EL abad contra el rey (y los regidores): conflicto de jurisdicciones y ejercicio del poder en Sahagún (1398-1417)

881 Manuel Alejandro Rodríguez de la Peña

Eusebius and Alcuin on Constantine and Charlemagne as Wise Rulers: Sapiential Rulership in Late Antiquity and the Early Middle Ages

9)15 Antonio SÁnCHEZ GonzÁlez

El Archivo de los Mariscales de Castilla y Marqueses de Malagón

\section{Estudios y comentarios}

9. 51 Serafín Olcoz Yanguas

Apostilla al estudio Influencia de las redes nobiliarias en la expansión cristiana del siglo XII: el caso de Soria (ETF, 33, 2020)

\section{Libros · Books}

969 CAstrillo CASAdo, Janire, Las mujeres vascas durante la Baja Edad Media (MARía Jesús Fuente)

973 Crónica del rey Juan II de Castilla. Minoría y primeros años de reinado (1406-1420) GARCIA, Michel (edición y estudio) (VÍctor MUÑ̃z GómEZ)

981 DA Silva, Marcelo Cândido, História Medieval (DIEgo CARLo AMÉNDOLLA SPÍNOLA)

9.87 Galende Díaz, Juan Carlos y Ávila SeoAne, Nicolás, El rodado regio hispánico. Fernando III de León y Castilla (12301252) (MAURICIO HERRERO JIMÉNEZ)

989 García IzQuierdo, Iván, Frontera, fuero y concejos. EI valle del Riaza en la Edad Media (siglos VIII-XII) (CARLOS BARQUERO GOÑI)

993 García IzQuierdo, Iván y Peterson, David (coords.), Camino y Señorío. Obra selecta de Luis Martínez García (ENRIQUe CANTERA MONTENEgRO)

995 GonzÁlez PAz, Carlos Andrés, O Bispado de Mondoñedo na Idade Media. Territorio, comunidade e poder (ENRIQUE CANTERA Montenegro) 


\section{4}

\section{ESPACIO,}

\section{TIEMPO}

Y FORMA

UกED

SERIE III HISTORIA MEDIEVAL

REVISTA DE LA FACULTAD DE GEOGRAFİA E HISTORIA

\section{Libros · Books}

9) López MARtínez, Amalia, Minutarios notariales de Estevo Pérez (Ourense, siglo XIV) (José MIgUel LóPEz VILLALBA)

999 Miranda García, Fermín y López de Guereño SAnz, María Teresa (eds.), La muerte de los príncipes en la Edad Media. Balance y perspectivas historiográficas (ANA ECHEVARRÍA ARSUAGA)

1003 Motis Dolader, Miguel Ángel, Vivencias, emocionesy perfiles femeninos. Judeoconversas e Inquisición en Aragón en el siglo XV (ANA ECHEVARría ARsuaga)

1007 Solórzano Telechea, Jesús Ángel y Martín PÉrez, Fernando (coords.), Rutas de comunicación marítima y terrestre en los reinos hispánicos durante la Baja Edad Media. Movilidad, conectividad y gobernanza (ENRIQUE JOSÉ RUIZ PILARES)

1013 TORRE, Sandra de la - ETXEBERRIA, Ekaitz - DíAz DE DURANA, José Ramón (coords.), Valer más en la tierra. Poder, violencia y linaje en el País Vasco bajomedieval (ENRIQUE CANTERA MONTENEGRO)

1015 TRILlo SAN José, Carmen, La Vega de Granada a partir de documentación árabe romanceada inédita (1457-1494). Estudio, edición e índices (INMACULADA GONZÁLEZ SOPEÑA)

1019 Val Valdivieso, M. ${ }^{a}$ Isabel - VillanueVa ZubizarReta, Olatz (Coords.), Pero Ansúrez. El conde, su época y su memoria (ENRIQUe CANTERA MONTENEGRO)

1021 Villanueva Morte, Concepción y Fernández de Córdova Miralles, Álvaro, El embajador Claver. Diplomacia y conflicto en las «Guerras de Italia» (1495-1504) (ENRIQUE Cantera Montenegro) 